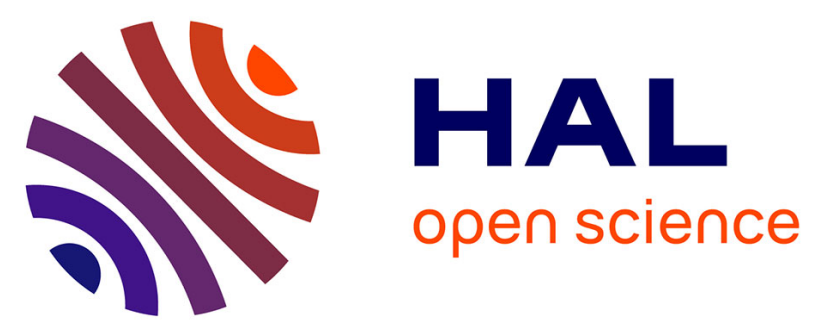

\title{
New Insights on the Chemical Composition of the Siberian Air Shed from the YAK-AEROSIB Aircraft Campaigns
}

\author{
Paris J.D., P. Ciais, Nédélec P., Stohl A., Belan B.D., Arshinov M.Y., \\ Carouge C., Golitsyn G.S., Granberg I.G.
}

\section{To cite this version:}

Paris J.D., P. Ciais, Nédélec P., Stohl A., Belan B.D., et al.. New Insights on the Chemical Composition of the Siberian Air Shed from the YAK-AEROSIB Aircraft Campaigns. Bulletin of the American Meteorological Society, 2010, 91 (5), pp.625-641. 10.1175/2009BAMS2663.1 . hal-00993403

\section{HAL Id: hal-00993403 https://hal.science/hal-00993403}

Submitted on 13 Jan 2021

HAL is a multi-disciplinary open access archive for the deposit and dissemination of scientific research documents, whether they are published or not. The documents may come from teaching and research institutions in France or abroad, or from public or private research centers.
L'archive ouverte pluridisciplinaire HAL, est destinée au dépôt et à la diffusion de documents scientifiques de niveau recherche, publiés ou non, émanant des établissements d'enseignement et de recherche français ou étrangers, des laboratoires publics ou privés. 


\section{NEW INSIGHTS ON THE CHEMICAL COMPOSITION OF THE SIBERIAN AIR SHED FROM THE YAK-AEROSIB AIRCRAFT CAMPAIGNS}

by Jean-Daniel Paris, Philippe Ciais, Philippe Nédélec, ANDREAs Stohl, Boris D. BeLAN, Mikhail Yu. Arshinov, Claire Carouge, Georgil S. Golitsyn, and Igor G. GranberG*
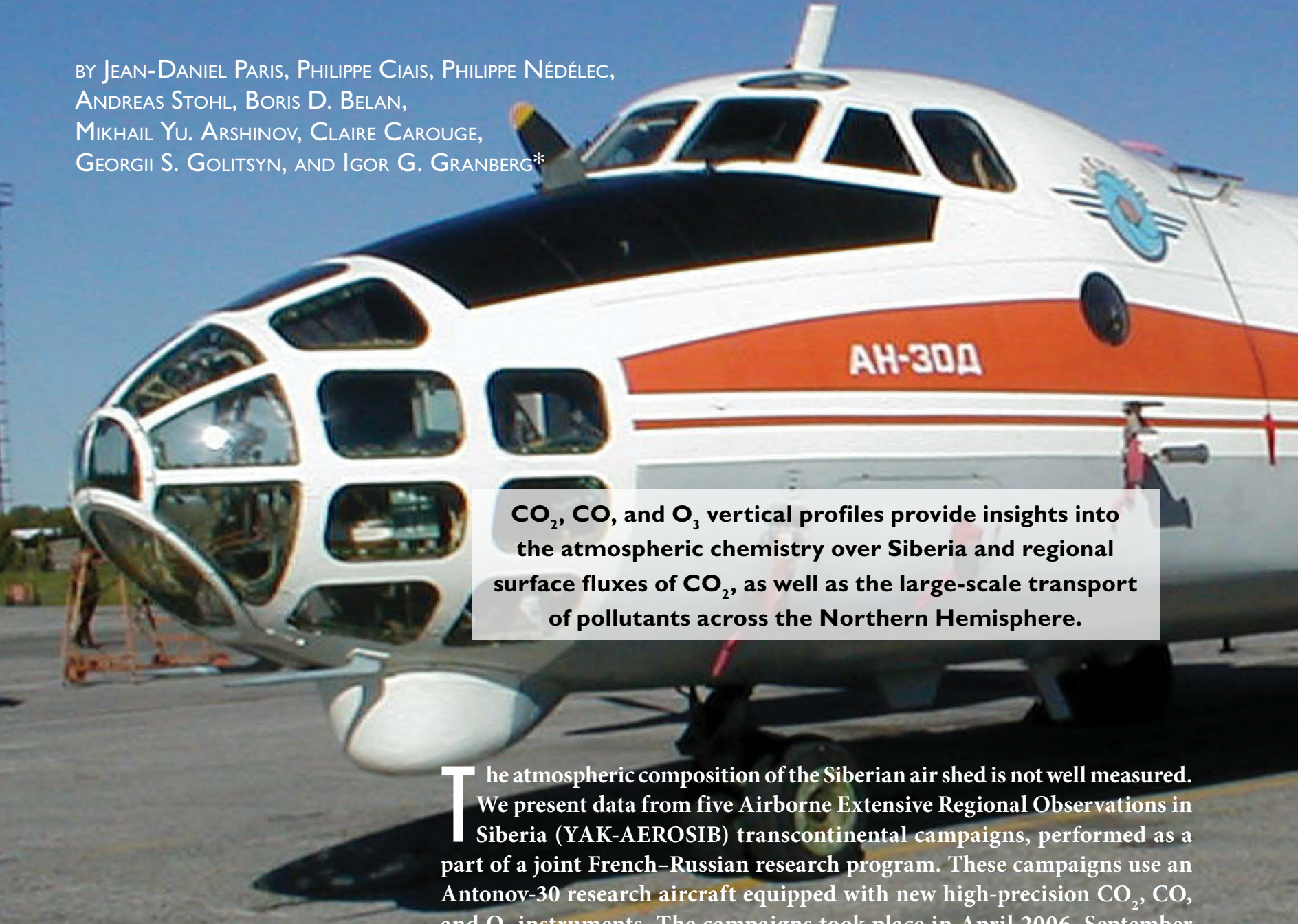

AH-801

$\mathrm{CO}_{2}, \mathrm{CO}$, and $\mathrm{O}_{3}$ vertical profiles provide insights into the atmospheric chemistry over Siberia and regional surface fluxes of $\mathrm{CO}_{2}$, as well as the large-scale transport of pollutants across the Northern Hemisphere.

Detail of the OPTIK-E research aircraft. See Fig. 3 for more, information.

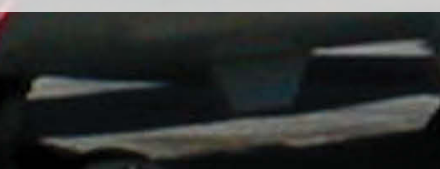

he atmospheric composition of the Siberian air shed is not well measured. We present data from five Airborne Extensive Regional Observations in

Siberia (YAK-AEROSIB) transcontinental campaigns, performed as a part of a joint French-Russian research program. These campaigns use an Antonov-30 research aircraft equipped with new high-precision $\mathrm{CO}_{2}, \mathrm{CO}$, and $\mathrm{O}_{3}$ instruments. The campaigns took place in April 2006, September 2006, August 2007, and twice in July 2008. About 50 in situ vertical profiles are collected during each campaign.

Atmospheric measurements can reduce uncertainties about surface sources and sink of $\mathrm{CO}_{2}$. We can infer surface fluxes from measured atmospheric $\mathrm{CO}_{2}$ concentration gradients using atmospheric tracer transport models. But deriving the distribution of $\mathrm{CO}_{2}$ fluxes in this way remains difficult because of scarce observations, in particular over the continents, and because of unknown biases in tracer transport models (Gurney et al.2002). The large spread between transport models results can be reduced by cross-validation against observed vertical $\mathrm{CO}_{2}$ profiles (Stephens et al. 2007). In continental areas, the shape of the vertical profile of $\mathrm{CO}_{2}$ is largely determined by 
the seasonal covariation of fluxes and atmospheric mixing, or "rectifier effect" (Denning et al. 1999). Carbon dioxide depletion due to uptake by plants during the growing season is vertically "diluted" by convection, homogeneously depleting $\mathrm{CO}_{2}$ in the deep boundary layer. On the other hand, $\mathrm{CO}_{2}$ losses to the atmosphere by ecosystems during the nongrowing season tend to accumulate near the surface under more stable atmospheric conditions, creating large positive $\mathrm{CO}_{2}$ gradients near the surface. The representation of this covariation differs widely among global transport models, plaguing the inverse modeling of $\mathrm{CO}_{2}$ fluxes given surface $\mathrm{CO}_{2}$ concentration observations. Siberia, with its large forested area and highly seasonal $\mathrm{CO}_{2}$ flux and transport, is a "hot spot" of $\mathrm{CO}_{2}$ transport model uncertainties (Gurney et al. 2002). In this context, new vertical profiles of $\mathrm{CO}_{2}$ provide a unique observational constraint on the seasonal coupling between flux and transport.

Affiliations: Paris, CiaIs, ANd Carouge-Laboratoire des Sciences du Climat et de l'Environnement, IPSL, CNRS-CEAUVSQ, Gif sur Yvette, France; NÉDÉLEC—Laboratoire d'Aérologie, Observatoire Midi Pyrénées, CNRS-UPS, Toulouse, France; StohL-NILU, Kjeller, Norway; BeLAN AND ARSHINOv-Zuev Institute of Atmospherics Optics, SB RAS, Tomsk, Russia; GolitsYN AND GRANBERG-Obukhov Institute of Atmospherics Physics, RAS, Moscow, Russia

*Deceased CORRESPONDING AUTHOR: Jean-Daniel Paris, LSCE/IPSL, CEA Saclay, L'Orme des Merisiers, 91191 Gif sur Yvette, France E-mail: jean-daniel.paris@Isce.ipsl.fr

The abstract for this article can be found in this issue, following the table of contents.

DOI:10.1175/2009BAMS2663.1

In final form 4 November 2009

(C) 2010 American Meteorological Society
Our expectation is to falsify atmospheric transport models over this region using the shape of observed vertical $\mathrm{CO}_{2}$ profiles.

Atmospheric pollutants released by human activities in midlatitude industrialized regions of the Northern Hemisphere (NH) quickly move over long distances. This intercontinental pollution transport has become of increasing concern because it affects local and regional air quality. The main pollution transport pathways (Fig. 1) differ qualitatively between north Asia (including Siberia), western Europe, and North America. Model simulations suggest that European pollutants predominantly disperse eastward over Siberia in summer or northeastward toward Siberia and the Arctic in winter (Stohl and Eckhardt 2004). Emissions from Europe remain mostly below $3,000 \mathrm{~m}$, unlike pollutants emitted by north Asia, which have a high probability of being transported into the upper troposphere (Wild et al. 2004; Stohl et al. 2002; Duncan and Bey 2004). The main pathways of intercontinental transport across the NH have been characterized by campaigns above and downwind from emission regions (e.g., Andreae 

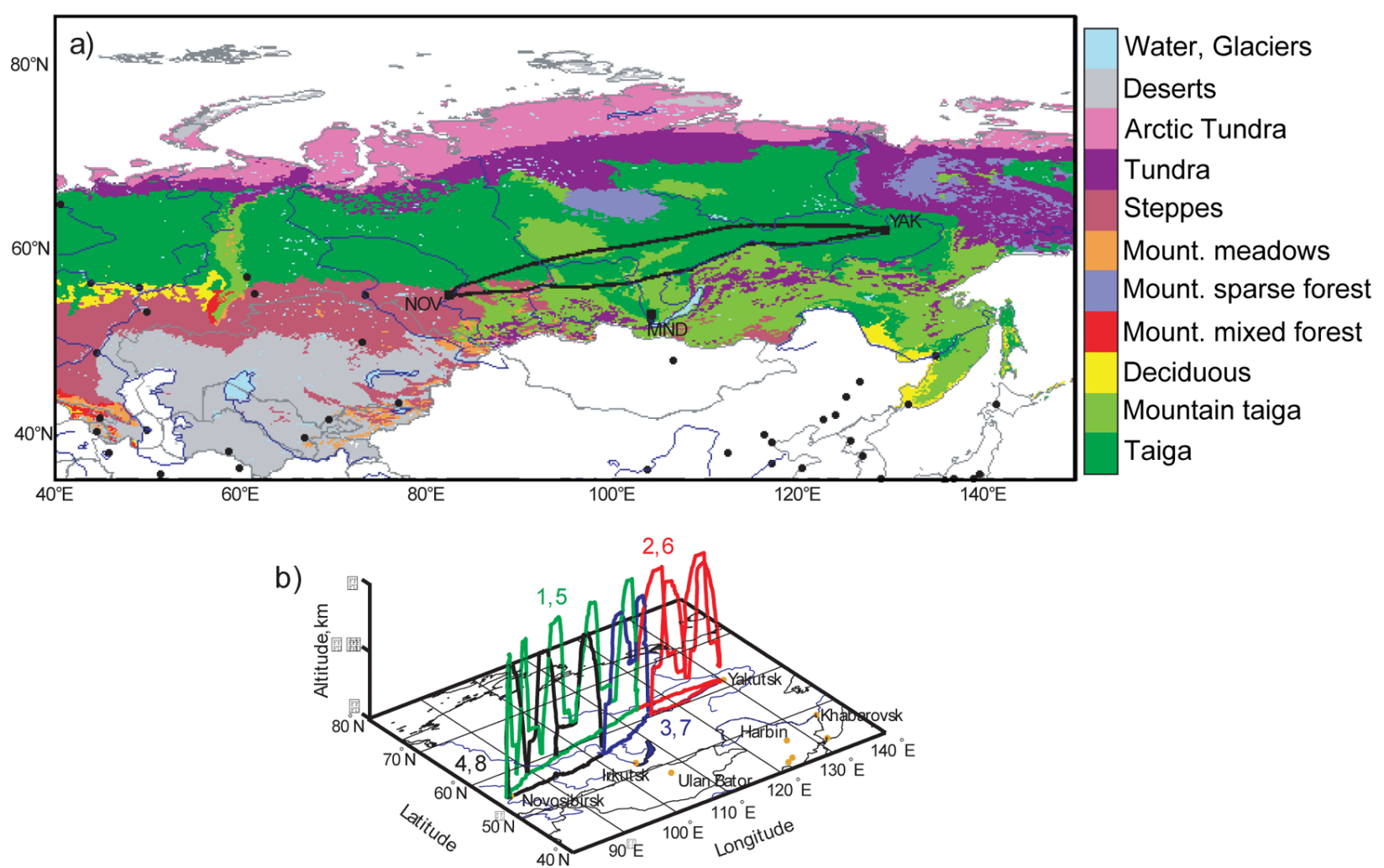

Fıg. 2. (a) Flight route and landscape classification. Each campaign follows a similar route, starting from Novosibirsk (NOV) in central Siberia, to the pivot point Yakutsk (YAK), and back to NOV. (b) A campaign is composed of four flights: the first is depicted in green, the second in red, the third in blue, and the fourth in black. The landscape classification is derived from Shvidenko et al. (2007).

et al. 1988; Lelieveld et al. 2002) and by satellite observations (Edwards et al. 2004) interpreted with models (Heald et al. 2004). However, no data are available over Siberia. According to models, Siberia is a region heavily impacted by the transport of pollution from Europe. In addition, summer forest fires (van der Werf et al. 2006) and prescribed agricultural fires in southern Siberia, Kazakhstan, and Ukraine (Korontzi et al. 2006) emit CO and ozone precursors that alter the Siberian chemical composition and more generally the CO budget of the NH (Wotawa et al. 2001).

The YAK-AEROSIB observational strategy addresses scientific questions about greenhouse gases and air pollution with large-scale airborne campaigns and synergistic use of different tracers. For instance, $\mathrm{CO}$ and $\mathrm{O}_{3}$ measurements are not only of interest for the atmospheric chemistry and transport research objectives, but they are also tracers of various processes that can help to analyze $\mathrm{CO}_{2}$ variability. Carbon monoxide and $\mathrm{CO}_{2}$ are coemitted during combustion, and both species remain correlated in the absence of removal processes. Ozone is depleted in the unpolluted boundary layer over vegetation because of deposition, in a way comparable to $\mathrm{CO}_{2}$ uptake by the vegetation. Also, in summer, concentrations of both $\mathrm{CO}_{2}$ and $\mathrm{O}_{3}$ are more elevated in the stratosphere than in the troposphere and can therefore be used to identify air of stratospheric origin.

Using the data collected during the campaigns, we seek a better understanding of the following science questions: What are the vertical distribution and seasonal variation of $\mathrm{CO}_{2}, \mathrm{CO}$, and $\mathrm{O}_{3}$ over Siberia? What does $\mathrm{CO}_{2}$ tell us as a transport tracer to constrain vertical mixing in models? What can we learn from a dense set of vertical profiles about synoptic transport and tracer mixing associated with frontal systems? Can we confirm by observations the model predictions that European pollutants are mainly exported to Siberia and the Arctic at low altitudes? We will show how these questions can be addressed with the data collected during YAK-AEROSIB.

CAMPAIGN DESCRIPTION. Flight area and experimental strategy. The four YAK-AEROSIB campaigns sampled the same transect of the Siberian troposphere (Fig. 2) using an Antonov-30 research 
aircraft called OPTIK-E (Fig. 3), operated by the Tomsk Institute of Atmospheric Optics. The campaigns' transect extended between Novossibirsk and Yakutsk, in a domain bounded by $55^{\circ}-63^{\circ} \mathrm{N}$ and $80^{\circ}-130^{\circ} \mathrm{E}$. Vertical profiles of tracers concentrations between 0 and 7,000 $\mathrm{m}$ were collected roughly every $200 \mathrm{~km}$ in the horizontal direction along the aircraft route. A fifth campaign in July 2008 covered Arctic and subarctic Siberia as part of the Polar Study using Aircraft, Remote Sensing, Surface Measurements and Models, of Climate, Chemistry, Aerosols, and Transport (POLARCAT) project.

The dominant vegetation type is deciduous (larch) and evergreen (spruce, pine) conifer forests, with forested bogs in the Yakutsk region and agricultural regions and steppes further south and west of the domain. Agriculture is present in the surroundings of Krasnoyarsk and Novosibirsk cities. The region has an extensive network of rivers and wetlands, including the Yenissei and Lena Rivers and their tributaries. The flight track also passed over several major cities and industrial and mining centers (Fig. 2, Table 1).

Each campaign (April 2006, September 2006, August 2007, and July 2008; see Table 1) was split into four flights with 4-10 vertical profiles each. Taking a profile takes about 30 minutes, including ascent and three horizontal plateaus: at the minimum altitude, at $5,000 \mathrm{~m}$ during the descent, and at the flight ceiling

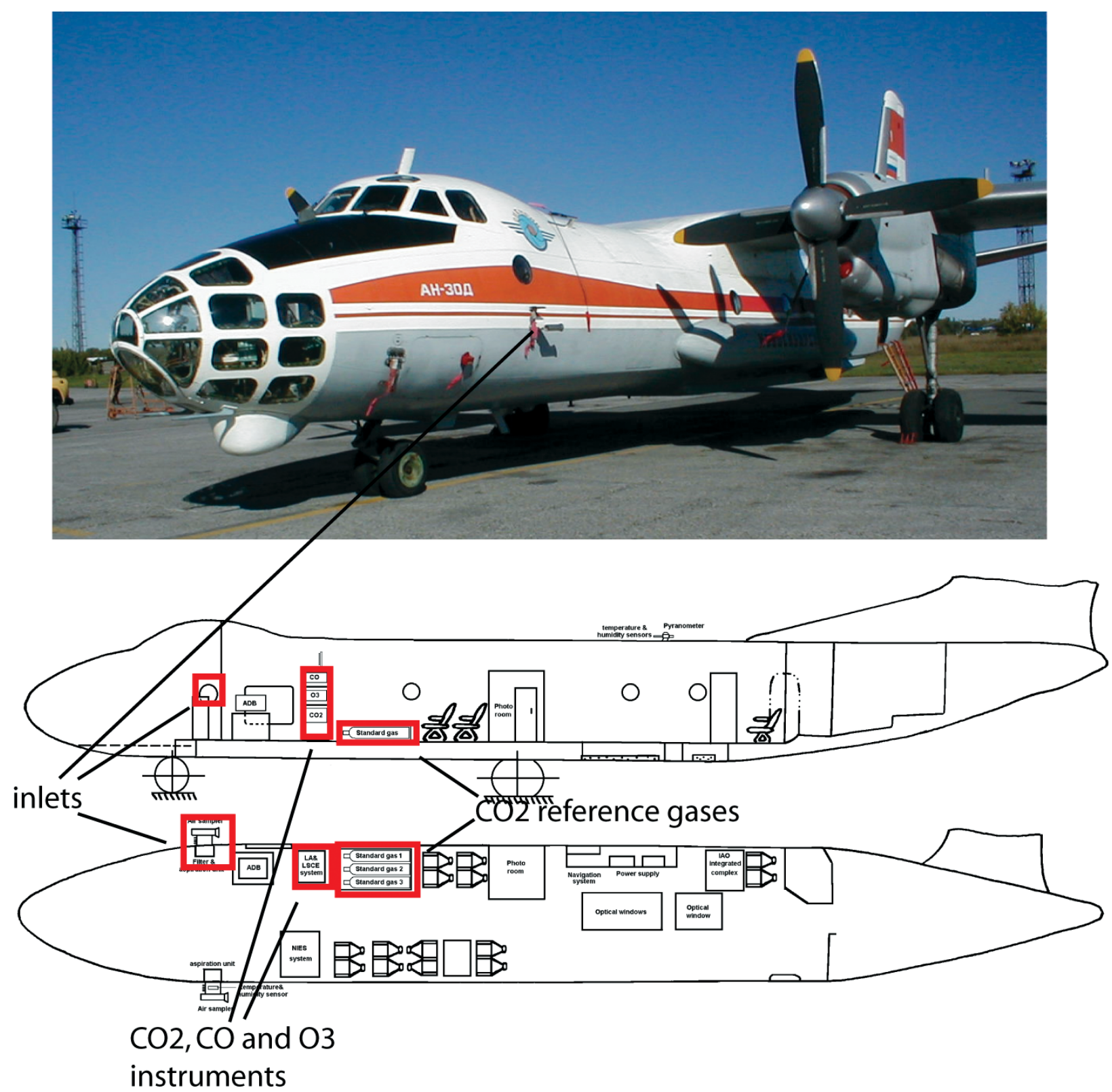

Fig. 3. Aircraft picture and schematics of interior. 
(approximately $7 \mathrm{~km}$ ). During each campaign, we measured in situ $\mathrm{CO}_{2}, \mathrm{CO}$, and $\mathrm{O}_{3}$ concentrations (Paris et al. 2008), as well as the (coarse resolution) size distribution of ultrafine particles (Arshinov et al. 2007; Paris et al. 2009), black carbon, and meteorological parameters. The appendix describes the instruments, calibration, and sampling protocols.

Meteorological context. ApRIL 2006 CAMPAIGN. The atmospheric circulation in the troposphere was dominated by a strong low on 11-14 April 2006 over eastern Siberia, blocking zonal circulation in northern Eurasia, and by a series of fronts sweeping across northeastern China during the 10 days prior to the campaign. High winds at the 700-mb level associated with the frontal passage were near the Russia-China border (Fig. 4a).
Warm conveyor belt (WCB) airstreams associated with these fronts can lift boundary layer (BL) air upward and northward. This favors accumulation and slow stirring of polluted Chinese boundary layer air within the stagnant midtroposphere over northeastern Siberia. In the lower troposphere, cold air and snow cover inhibited the growth of a BL over Siberia, enhancing stagnant conditions.

September 2006 campaign. Warmer conditions, as well as local convection and precipitation were observed, with fronts of various strengths within northern Eurasia, including a large front over the Caspian Sea area. The atmospheric circulation was more zonal than during the April campaign because of a high pressure system between the Aral Sea and Mongolia.

\begin{tabular}{|c|c|c|c|c|c|}
\hline Flight No. & Date & Hours, LT & Hours, UTC & Nb profiles & Itinerary \\
\hline I & II Apr 2006 & $1200-2100$ & $0600-1200$ & 8 & Novossibirsk-Myrni \\
\hline 2 & 12 Apr 2006 & $1100-1530$ & $0200-0630$ & 8 & Myrni-lakutsk-Lensk \\
\hline 3 & 12 Apr 2006 & $1730-1900$ & $0830-1100$ & 4 & Lensk-Bratsk \\
\hline 4 & 14 Apr 2006 & $0830-1030$ & $0030-0430$ & 6 & Bratsk-Novossibirsk \\
\hline 5 & 7 Sep 2006 & $0900-1900$ & $0300-1000$ & 10 & Novossibirsk-Myrni \\
\hline 6 & 8 Sep 2006 & $0945-1430$ & $0045-0530$ & 8 & Myrni-lakutsk-Lensk \\
\hline 7 & 8 Sep 2006 & $1600-1730$ & $0700-0930$ & 2 & Lensk-Bratsk \\
\hline 8 & 10 Sep 2006 & $0900-1115$ & $0100-0515$ & 6 & Bratsk-Novossibirsk \\
\hline 9 & 17 Aug 2007 & $0930-1815$ & $0330-0915$ & 10 & Novossibirsk-Myrni \\
\hline $10^{\mathrm{a}}$ & 18 Aug 2007 & $0725-1200$ & $2225-0300$ & 8 & Myrni-lakutsk-Lensk \\
\hline II & 18 Aug 2007 & $1315-1445$ & $0415-0645$ & 4 & Lensk-Bratsk \\
\hline 12 & 20 Aug 2007 & $0830-1000$ & $0030-0400$ & 6 & Bratsk-Novossibirsk \\
\hline 13 & 7 Jul 2008 & $0640-1515$ & 0400-0915 & 8 & Novossibirsk-Salekhard \\
\hline 14 & 7 Jul 2008 & $1810-0115$ & $1210-1615$ & 4 & Salekhard-Khatanga \\
\hline 15 & $8 \mathrm{Jul} 2008$ & $1045-1515$ & $0145-0615$ & 6 & Khatanga-Chokurdakh \\
\hline $16^{\mathrm{b}}$ & 9 Jul 2008 & $0630-1150$ & $2130-0250$ & 8 & Chokurdakh-Pewek-Chokurdakh \\
\hline 17 & II Jul 2008 & $0920-1240$ & $0020-0340$ & 6 & Chokurdakh-lakutsk \\
\hline 18 & II Jul 2008 & $1455-1535$ & $0555-0835$ & 4 & lakutsk-Myrni \\
\hline 19 & 12 Jul 2008 & $0850-1240$ & $0150-0740$ & 8 & Myrni-Novossibirsk \\
\hline 20 & $21 \mathrm{Jul} 2008$ & $1125-2050$ & $0525-1150$ & 8 & Novossibirsk-Myrni \\
\hline 21 & 23 Jul 2008 & $1030-1530$ & $0130-0630$ & 8 & Myrni-lakutsk-Lensk \\
\hline 22 & 23 Jul 2008 & $1720-1915$ & $0820-1115$ & 4 & Lensk-Bratsk \\
\hline 23 & 25 Jul 2008 & $0910-1410$ & $0110-0610$ & - & Lake Baïkal \\
\hline $24^{c}$ & 28 Jul 2008 & $0745-1325$ & $2345-0525$ & - & Lake Baïkal \\
\hline 25 & 29 Jul 2008 & 0855-1345 & $0055-0745$ & 6 & Bratsk-Novossibirsk \\
\hline
\end{tabular}

a Takeoff on 17 Aug 2007 at 2225 UTC; most of the flight on 18 Aug in UTC.

b Takeoff on 9 Jul in UTC and landing on 10 Jul.

c Takeoff on $27 \mathrm{Jul}$ in UTC. 
(a) Apr 112006

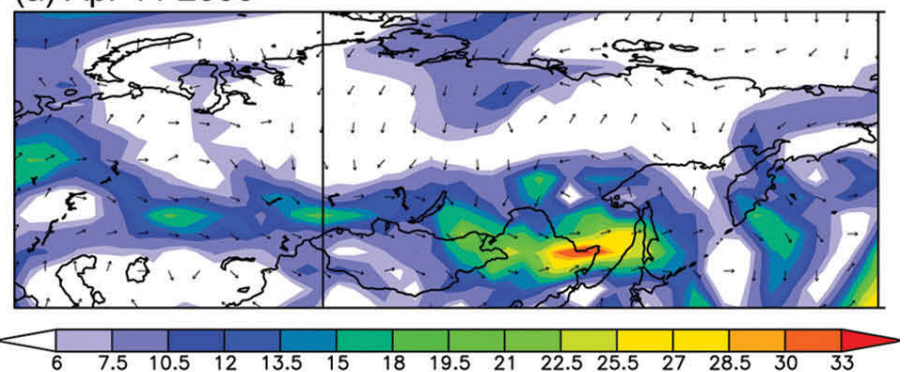

(b) Sep 072006

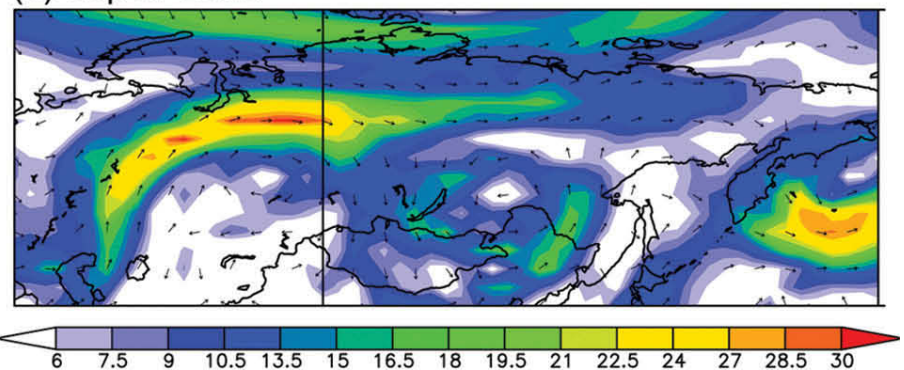

(c) Aug 172007

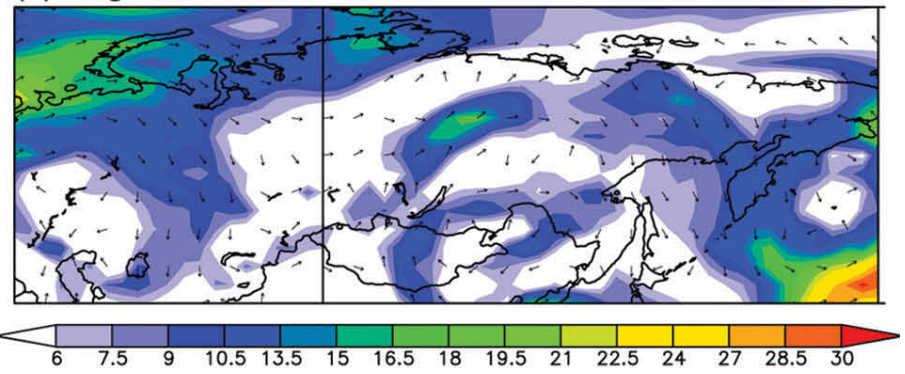

(d) Jul 072008

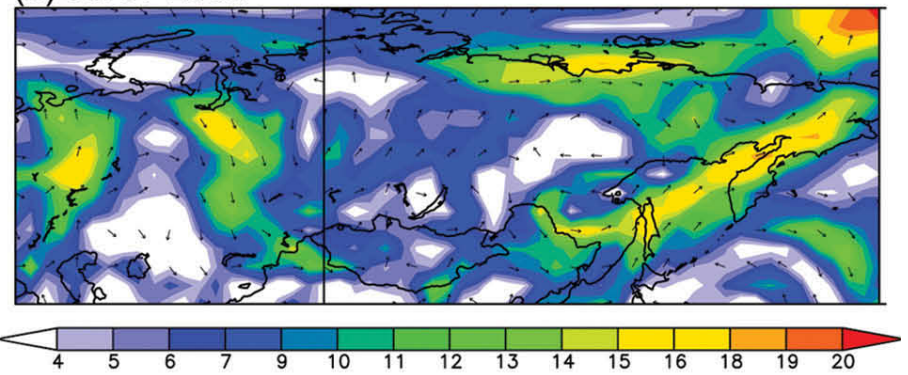

(e) Jul 212008

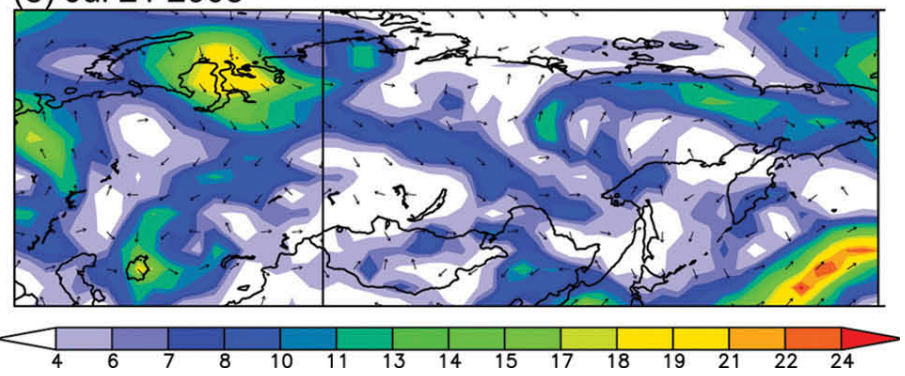

Fig. 4. Wind field $\left(\mathrm{m} \mathrm{s}^{-1}\right)$ at $700 \mathrm{mbar}$ from the National Centers for Environmental Prediction (NCEP) reanalysis data (Kalnay et al. 1996) on the first day of each campaign. Provided by the NOAA/ESRL Physical Sciences Division, Boulder, Colorado (www.esrl.noaa.gov/psd/).
As a result, air masses originating from the Caspian Sea area were transported far away into Siberia (Fig. 4b).

August 2007 CAMPAIGN. The zonal circulation over central Siberia was slower than in September 2006. This campaign was dominated by convective mixing. Low pressure southwest of Novosibirsk caused strong winds early in the campaign. Flights 9 and 10 frequently crossed rainbands (Table 1 ). In particular, flight 9 on 17 August first passed through a strong front and then through a weak front. Air masses were channelled to the southeast out of the north Asian landmass (Fig. 4c).

July 2008 Campaigns. These two campaigns had much weaker winds than the previous three (Figs. 4d,e). During the YAK-AEROSIB campaign, fronts of various strengths were identified along the flight track. A sparse to nearly continuous cover of low clouds generally dominated both July 2008 campaigns. On 11 July, a strong low pressure system west of the flight track near Yakutsk caused vigorous frontal activity. Fires were also observed in this area. During the POLARCAT campaign, steep frontal surfaces were crossed. Along the Arctic coast, where four flights were executed, the sea was ice covered and skies were mostly cloudy.

Summary. Atmospheric transport in April 2006 over western Siberia likely was representative of average winter conditions (Fig. 1). Convection was weak because of the low surface temperatures and snow. The strength and position of airstreams associated with synoptic transport features (warm conveyor belts and dry intrusions) were also typical of winter conditions (Stohl 2001), although zonal transport is on average attenuated in April relative to its winter maximum (Newell and Evans 2000). Atmospheric transport during the four summer campaigns varied, even though fronts, cloud cover, and other features were frequently similar during each flight. The zonal flow encountered during September 2006 was stronger than in August 2007 and July 2008. This is broadly consistent with 
the summer minimum in zonal transport shown by Newell and Evans (2000).

\section{VERTICAL AND HORIZONTAL VARIABIL-} ITY OF $\mathrm{CO}_{2}$, CO, AND $\mathrm{O}_{3}$ OVER SIBERIA.

Carbon dioxide. Over Siberia, $\mathrm{CO}_{2}$ concentrations are highest at the end of the winter (early March) when vegetation resumes growth in the $\mathrm{NH}$ (Levin et al. 2002). The $\mathrm{CO}_{2}$ distribution measured from aircraft is sensitive to the diurnal and seasonal cycle of $\mathrm{CO}_{2}$ exchange (i.e., during growing season, photosynthesis during daytime counteracts the diurnally less variable emissions from respiration) but also to the frontal redistribution of air masses. Here, possible daytime sampling bias is minimized because sampling was conducted on average over all daylight hours. Average vertical profiles for each flight are shown in Fig. 5. The seasonal difference of $\mathrm{CO}_{2}$ obtained by com-

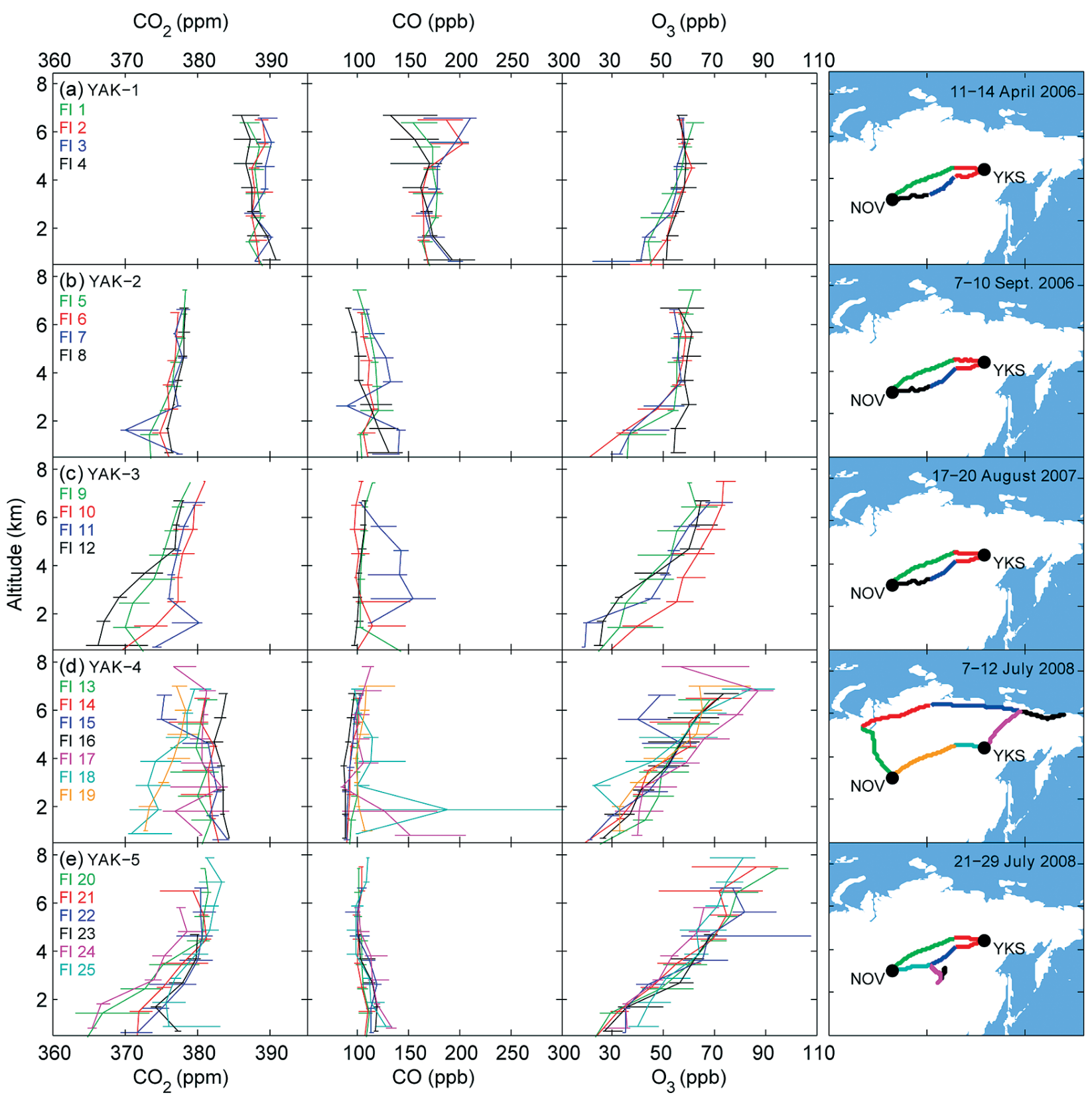

Fig. 5. Profiles of (left) $\mathrm{CO}_{2}$, (middle left) $\mathrm{CO}$, and (middle right) $\mathrm{O}_{3}$ over the five campaigns (in rows). (right) Flight tracks are shown for each campaign, with the same color code as the vertical profiles. Each profile is averaged in 1000-m bins and comprises 4-8 h of flight (i.e., about 4-10 individual ascents/descents). The horizontal bars at each altitude bin show the extent of the interquartile (25th and 75 th percentile) of concentrations in each bin. 
paring April 2006 and September 2006 is 14.3 ppm below $2 \mathrm{~km}$, and $10.8 \mathrm{ppm}$ between 3 and $7 \mathrm{~km}$. This seasonal $\mathrm{CO}_{2}$ difference is comparable in amplitude to the one measured at the Zotino site in central Siberia of 13-15 ppm below 3,000 m (Levin et al. 2002; Lloyd et al. 2002). The carbon balance of Eurasia in April 2006 was characterized by vegetation dormancy (Shibistova et al. 2002) with no $\mathrm{CO}_{2}$ exchange fluxes over snow-covered Siberia (Smith et al. 2004) and by growth with $\mathrm{CO}_{2}$ uptake over Europe and southern regions (Zhou et al. 2001; Maignan et al. 2008; Reichstein et al. 2007).

August marks the termination of the $\mathrm{CO}_{2}$ uptake period over Siberia, with flux tower data consistently indicating a switch in $\mathrm{CO}_{2}$ exchange by regional ecosystems from a sink to a source at around day $250 \pm 10$ (Van der Molen et al. 2008). Consequently, atmospheric $\mathrm{CO}_{2}$ in the Siberian troposphere usually reaches a seasonal minimum by the end of August (Levin et al. 2002; Lloyd et al. 2002; Ramonet et al. 2002; Machida et al. 2001). The August 2007 and July 2008 campaigns experienced convective weather in central Siberia with cumulus fields and rainfall. From July and August $\mathrm{CO}_{2}$ values near the surface we infer that Siberian ecosystems behave as a strong and apparently homogeneous sink, causing a $\mathrm{CO}_{2}$ depletion of up to $10 \mathrm{ppm}$ in August and up to $15 \mathrm{ppm}$ in July (Figs. 5, 6) into the low troposphere over the western part of the campaign. In September 2006, although the vegetation was still active (green from space) over Siberia, we observed no strong near-surface $\mathrm{CO}_{2}$ depletion.

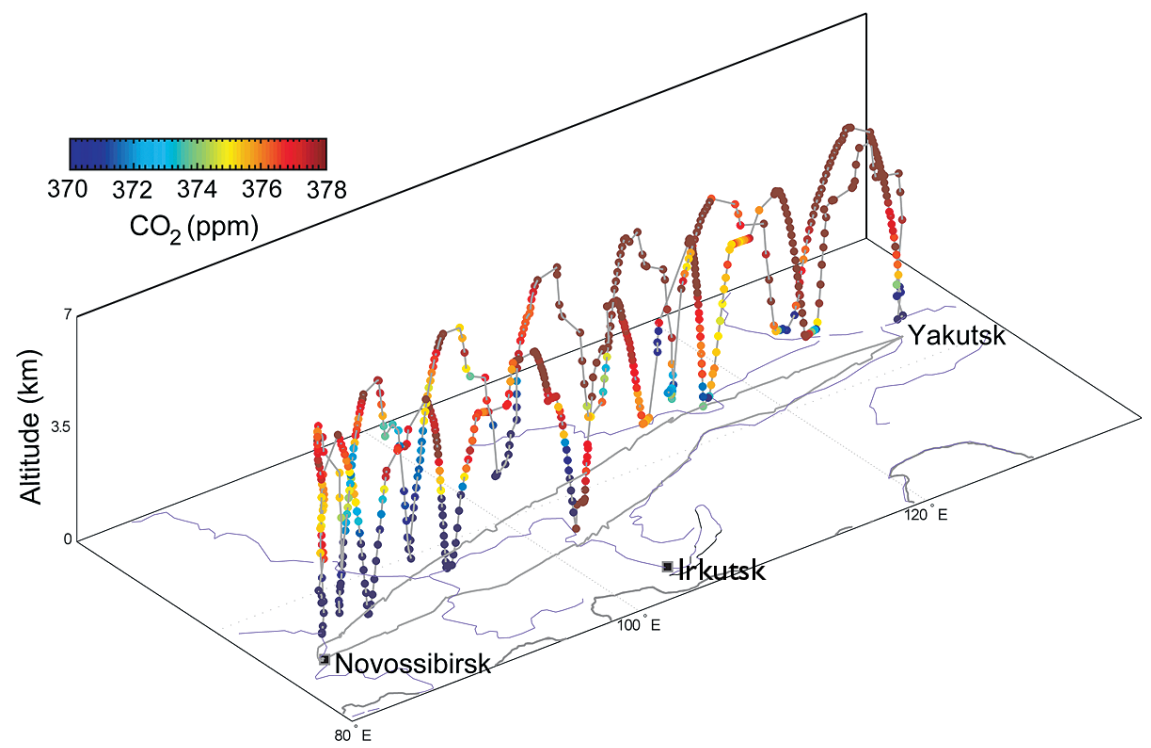

Fig. 6. Three-dimensional representations of $\mathrm{CO}_{2}$ measurements during Aug 2007. The cities of Novosibirsk and Irkutsk near Lake Baikal are represented by black squares.
Ozone. Figure 5 (middle right column) provides the $\mathrm{O}_{3}$ vertical profiles. The vertical gradient of $\mathrm{O}_{3}$ is more than 2 times steeper in July and August than in April or September 2006, with a more pronounced $\mathrm{O}_{3}$ depletion near the surface in early summer. In August, the midtropospheric $\mathrm{O}_{3}$ concentrations between 5 and $7 \mathrm{~km}$ ranged from 60 to $80 \mathrm{ppb}$, whereas they reached only 50-65 ppb in April and September. Thin layers with high $\mathrm{O}_{3}$ concentrations ( $80 \mathrm{ppb}$ and higher), probably originating from the stratosphere, were repeatedly observed in the midtroposphere. The July and August steeper $\mathrm{O}_{3}$ vertical gradient can be explained by a combination of factors: 1) More intense photochemical production of $\mathrm{O}_{3}$ in August 2007, coupled to convective injection to the midtroposphere of precursors initially emitted in the BL. 2) Higher surface biogenic volatile organic compounds (BVOCs) emissions contribute to higher $\mathrm{O}_{3}$ production in summer (Fehsenfeld et al. 1992). Boreal deciduous trees and spruce monoterpene emissions are indeed highest in July-August (Tarvainen et al. 2007), while pine emissions peak in the early summer. 3) Maximum foliar and surface deposition in summer cause a depletion of $\mathrm{O}_{3}$ in the $\mathrm{BL}$, and 4) the temperature-dependent $\mathrm{O}_{3}$ reaction with BVOCs within the canopy could act as significant additional surface sink of $\mathrm{O}_{3}$ (Goldstein et al. 2004).

The summer $\mathrm{O}_{3}$ gradient increased with time of day, with the $\mathrm{O}_{3}$ concentration in the $\mathrm{BL}$ dropping at a rate of $2.6 \mathrm{ppb} \mathrm{h}^{-1}$ (noted between 1000 and 1600 LT on 16 August 2007). This decrease of $\mathrm{O}_{3}$ was spatially very homogeneous despite the large distance between profiles $(200 \mathrm{~km})$ and the rather heterogeneous vegetation coverage. This suggests that strong near-surface deposition and photochemical processes were the dominant cause of the observed pronounced $\mathrm{O}_{3}$ vertical gradient in the August 2007 flights. The July 2008 flights (Fig. 5e) repeatedly ( $4 \%$ of the time) crossed air with high $\mathrm{O}_{3}$ concentrations (>100 ppb) above $5 \mathrm{~km}$.

Carbon monoxide. Carbon monoxide concentrations were highest during the April 2006 campaign, as shown by Fig 5 . The mean 
tropospheric $\mathrm{CO}$ concentration during that campaign was $170 \mathrm{ppb}$, a surprisingly high value for supposedly "clean" Siberian air, in absence of significant local $\mathrm{CO}$ emissions from industry or wildfires. The background $\mathrm{CO}$ value was determined in each campaign from the profile sections with the lowest CO variability (Paris et al. 2008) and was $135 \mathrm{ppb}$ in April 2006. The CO concentration measured by the YAK-AEROSIB flights in April 2006 was even higher than that routinely measured in April over Frankfurt, Germany, by the Measurement of Ozone and Water Vapor by Airbus In-Service Aircraft (MOZAIC) program (Marenco et al. 1998), which suggests long-range advection of $\mathrm{CO}$ from remote industrialized regions. Indeed, $\mathrm{CO}$, pollutants, and dust accumulated in the BL over northern China in April 2006 were swept by a series of cold fronts and uplifted over eastern Siberia (Paris et al. 2008). In the summer campaigns, we found remarkably homogeneous concentrations. Over all data, the September campaign showed a median $\mathrm{CO}$ concentration of $108 \mathrm{ppb}$ (with 25th and 75th percentiles of 100 and $119 \mathrm{ppb}$ ), 105 ppb in August 2007 (interquartile range 100-111 $\mathrm{ppb})$, and $102 \mathrm{ppb}$ in July 2008 (95-110 ppb). This is consistent with a shorter lifetime for $\mathrm{CO}$ in summer but also with a combination of reduced export of pollution from Europe due to weaker zonal circulation and marginal local anthropogenic emissions.

\section{$\mathrm{CO}_{2}$ AS A TRACER OF VERTICAL AND HORIZONTAL MIXING IN MODELS. $\mathrm{CO}_{2}$} observations from the YAK-AEROSIB campaigns can be used to evaluate large-scale transport models, thanks to the continent-wide extent of the flights and the density of vertical profiles. Carbon dioxide as a long-lived tracer is capable of constraining vertical mixing in models (Stephens et al. 2007). Its atmospheric budget is dominated by emissions from fossil fuel combustion, ameliorated by ocean uptake and by seasonally varying plant uptake. Surface $\mathrm{CO}_{2}$ gradients of a few parts per million are mixed in the vertical at the synoptic scale (e.g., Yi et al. 2004; Chan et al. 2004; Sarrat et al. 2007) and advected over very long distances (e.g., Wada et al. 2007).

Vertical mixing of $\mathrm{CO}_{2}$ and rectification gradients. The seasonal $\mathrm{CO}_{2}$ vertical gradient observed over $\mathrm{NH}$ continents, in particular over Siberia, is determined by seasonal covariation between transport and biospheric fluxes, or seasonal rectifier effect (Denning et al. 1999). This effect causes a mean annual accumulation near the continental surface, causing a positive interhemispheric surface gradient. Unfortunately, global transport models used for $\mathrm{CO}_{2}$ studies give very different results in simulating these rectification gradients (Rayner and Law 1995; Law et al. 1996). This uncertainty biases the diagnostic of surface fluxes in inversions (Gurney et al. 2002). Because the spread of transport model results for $\mathrm{CO}_{2}$ reflects their differences in vertical and horizontal mixing, Stephens et al. (2007) and Yang et al. (2007) showed that independent vertical profile data can falsify models, and in the long run can be used to test their parameterizations.

Stephens et al. (2007) performed a cross-validation study of 13 transport models with optimized fluxes constrained by surface stations, by using vertical profiles. They compiled a climatology of Northern Hemispheric vertical $\mathrm{CO}_{2}$ profiles from 12 aircraft sites and applied it to the Atmospheric Tracer Transport Model Intercomparison Project (TRANSCOM) group of transport models (Baker et al. 2006). Despite being prescribed with fluxes that optimally fit the surface data for each model, nearly all the TRANSCOM models show a common bias compared to the observed vertical profiles. The sign of this bias suggests that vertical mixing is likely underestimated in wintertime and overestimated in summertime. Moreover, a clear relationship was found between vertical transport bias in the $\mathrm{NH}$ and the global balance between tropical and northern carbon sinks. Thus, transport models can be differentiated as having greater consistency with the observed $\mathrm{CO}_{2}$ vertical gradient.

We applied the YAK-AEROSIB data to this problem. Unlike Stephens et al. (2007), we cannot use a large number of aircraft sites or monthly coverage. However, the large spatial representativeness of the campaigns allows for substituting the low temporal density with a high spatial density of vertical profiles across Siberia, the region where transport models differ the most (Denning et al. 1999; Law et al. 1996). For example, Fig. 7 compares the first three YAK-AEROSIB campaigns with $\mathrm{CO}_{2}$ vertical distribution from one transport model, the Laboratoire de Météorologie Dynamique AGCM (LMDz)Interaction with Chemistry and Aerosols (INCA) model without optimized fluxes. LMDz-INCA is a global chemistry-climate model (Sadourny and Laval 1984; Hauglustaine et al. 2004; Brunner et al. 2005) of horizontal resolution $3.75^{\circ} \times 2.5^{\circ}$ with 19 vertical levels. The biogenic $\mathrm{CO}_{2}$ fluxes are prescribed from the Carnegie Ames Stanford Approach (CASA) terrestrial ecosystem model (Potter et al. 1993) and the anthropogenic emissions from the Emission Database for Global Atmospheric Research (EDGAR) fast-track 2000 database (Olivier et al. 2005). Biomass burning 

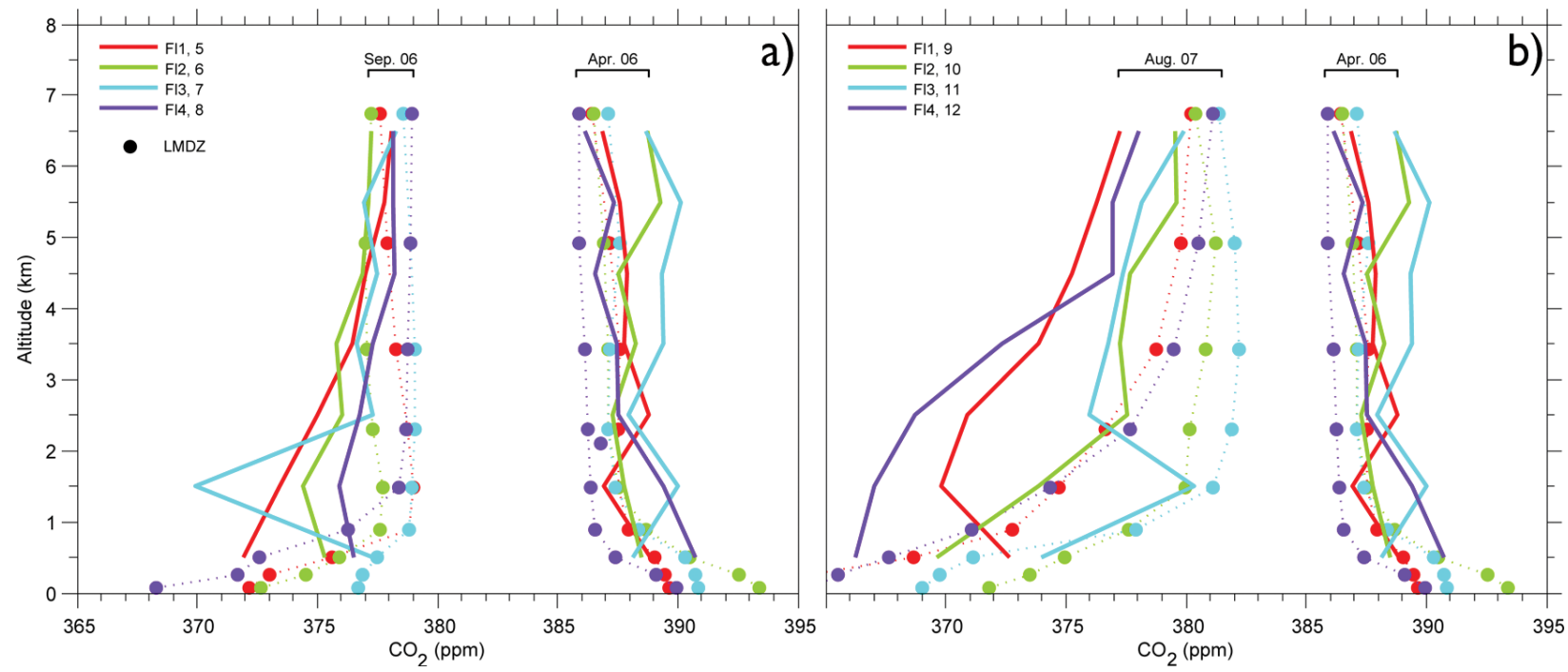

Fig. 7. Estimation of model vertical mixing with $\mathrm{CO}_{2}$ as a tracer of transport. Each profile corresponds to a flight averaged over 1000-m bins. (a) Comparison of Apr and Sep 2006 campaigns. (b) Comparison of Apr 2006 and Aug 2007 campaigns. Model results are shown as color dots on dotted lines; measurements are thick lines.

emissions are not included in this model simulation. Figure 7 shows that LMDz-INCA underestimates $\mathrm{CO}_{2}$ vertical mixing in winter and overestimates it in summer. As transport models are particularly deficient over Siberia with model results deviating strongly from each other (Gurney et al. 2002), reducing their spread over this region by cross-validation will also help to reduce uncertainties elsewhere in the $\mathrm{NH}$.

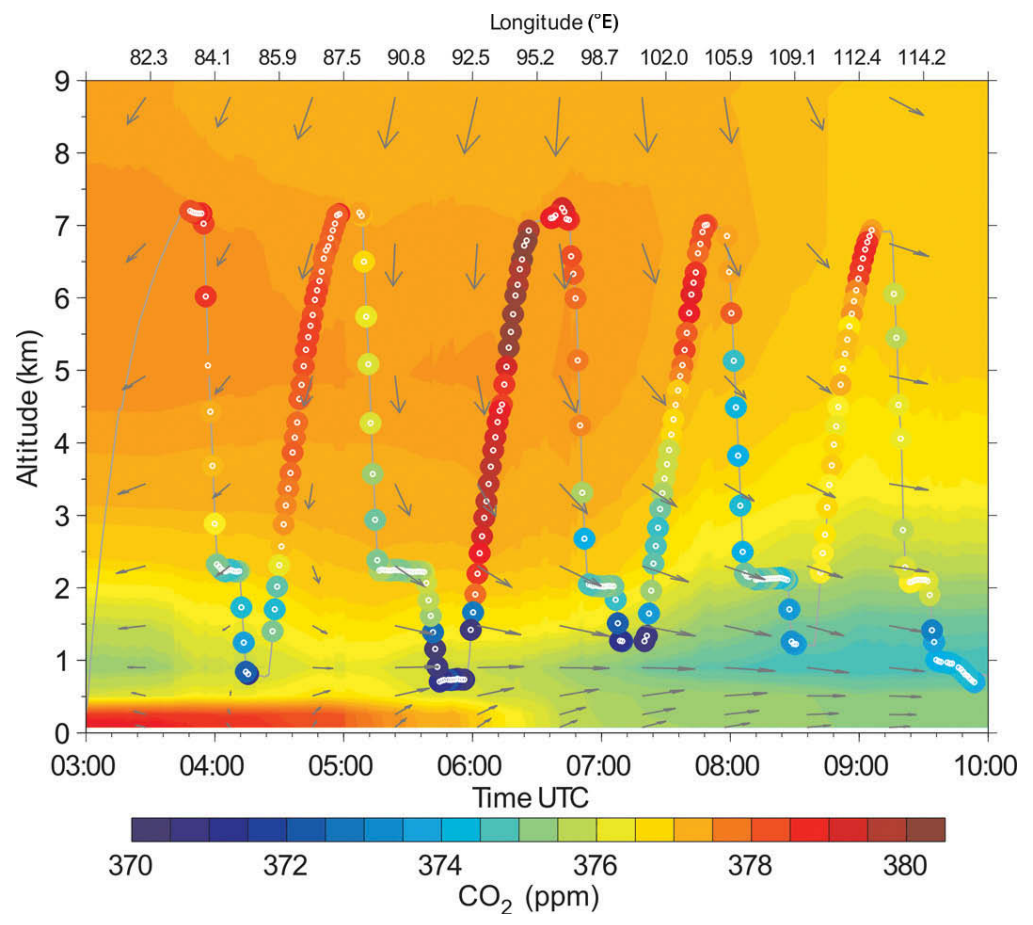

FIG. 8. Carbon dioxide along flight 5 on 7 Sep 2006. The in situ measured $\mathrm{CO}_{2}$ (dots) is superimposed on the $\mathrm{CO}_{2}$ profile interpolated from the LMDz-INCA chemistry GCM (background). Note that the color scale is the same for data and observations. The gray arrows represent the horizontal wind (north upward).
Horizontal and vertical mixing of $\mathrm{CO}_{2}$. Figure 8 shows $\mathrm{CO}_{2}$ simulated by LMDz-INCA during flight 5 on 7 September 2006. Flight 5 was selected because the aircraft crossed a weak front during the second and third profiles, and the imprint of the synoptic circulation near the front is clearly visible in the $\mathrm{CO}_{2}$ data (color dots in Fig. 8; see also Fig. 5b). The modeled $\mathrm{CO}_{2}$ field interpolated to the aircraft positions is in good agreement with the observations (Fig. $8 ; R^{2}=0.46, \mathrm{n}=412$ ), but the $\mathrm{CO}_{2}$ variability is underestimated by a factor of 2.5. LMDz-INCA reproduces qualitatively the $\mathrm{BL}$-free troposphere negative $\mathrm{CO}_{2}$ gradient (between 1- and 3-km altitude) and synoptic patterns crossed between 0400 and 0600 UTC. However, it fails to capture the true BL height, below which $\mathrm{CO}_{2}$ is more depleted because of plant uptake. The $\mathrm{CO}_{2}$ vertical gradient in the model is not as steep as in the data. A limitation 
of such a model-data comparison limited to a particular flight is the accuracy of biogenic $\mathrm{CO}_{2}$ fluxes. The overestimated $\mathrm{CO}_{2}$ value $(\sim 379 \mathrm{ppm})$ below $400 \mathrm{~m}$ from 0300 to 0500 UTC (1000-1200 LT) in Fig. 8 can be due to an overestimated $\mathrm{CO}_{2}$ source by the vegetation.

Moreover, LMDz-INCA calculations for the case study of $\mathrm{CO}_{2}$ transport shown in Fig. 8 suggest that, in September 2006, European fossil fuel $\mathrm{CO}_{2}$ emissions were advected into the Siberian airshed between $50^{\circ}$ and $70^{\circ} \mathrm{N}$, causing $\mathrm{CO}_{2}$ concentrations to be enhanced by $\sim 0.5 \mathrm{ppm}$ between 2 - and $4-\mathrm{km}$ altitude. In the next section, we will show that this is consistent with backward Lagrangian particle dispersion model analysis.

\section{POLLUTION OVER SIBERIA AND SOURCE}

REGIONS. Little is known about how remote pollution sources influence Siberia. Models predict a dominance of low-level advection of European pollutants to Siberia (Wild et al. 2004; Duncan and Bey 2004) but this has received little experimental support (Pochanart et al. 2003). We applied the backward Lagrangian particle dispersion model FLEXPART (Stohl et al. 2005; Seibert and Frank 2004) to attribute two observed salient $\mathrm{CO}_{2}$ and $\mathrm{CO}$ plumes to their region of origin. FLEXPART computes back trajectories for a large number of particles, with improved airmass transport representation. For any given receptor (instrument) position, FLEXPART maps the transport "footprint" associated to the measure- ment, that is, the areas from where surface emissions can potentially reach the receptor at a given sampling time, with up to 20 days of backward transport. This footprint is called the potential emission sensitivity (PES).

Long-range transport of fire and European emission versus clean Arctic air (September 2006). We focus here on the origin of layers observed during the September 2006 campaign. Measurements of $\mathrm{CO}_{2}, \mathrm{CO}$, and $\mathrm{O}_{3}$ on 7 September 2006 (flight 5) show significantly polluted plumes (Fig. 9). The color shading in Fig. 9 results from an objective classification scheme based on similarity between the PES associated to each observation (Paris et al. 2010). The orthogonal classification of the PES is independent from measured concentrations. This allows identifying and further comparing different air masses that compose each profile. Two types of layers are dominant: polluted layers traceable to airstreams of European-Caspian Sea origin and clean-air layers traceable to an Arctic origin. These two groups are well separated in terms of tracer concentrations.

FLEXPART analysis shows that all Arctic clean-air layers (light blue in Fig. 9) are characterized by a long residence time (>10 days) inside the polar vortex. The associated low $\mathrm{CO}$ and $\mathrm{CO}_{2}$ concentrations (Table 2) suggest a strong isolation of these air masses from sources in their recent history, consistent with long residence time of air in the Arctic in summer (Stohl 2006). The FLEXPARTcalculated PES further indicates that advection of Arctic air sampled during September 2006 occurs in the BL. During the five days of meridional transport from the Arctic to the sampling location of flight 7 , exchange with
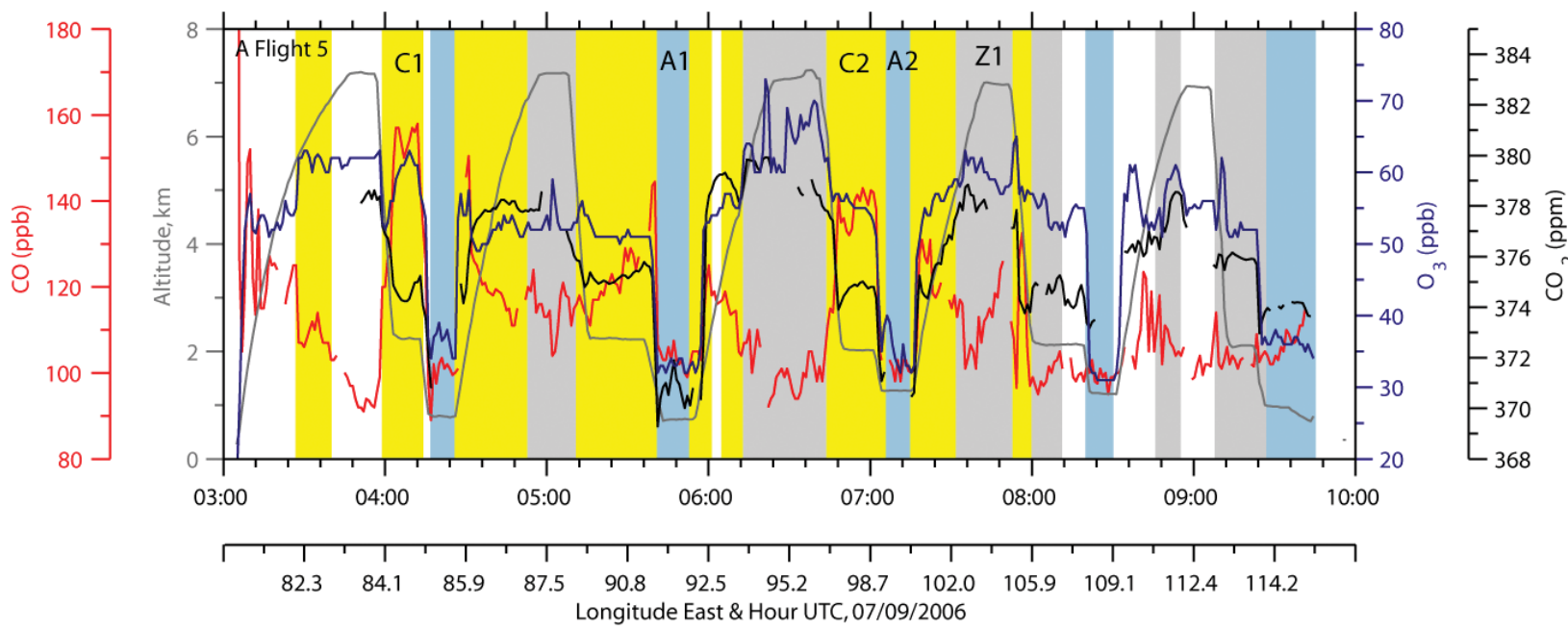

Caspian

Arctic

Zonal

Fig. 9. Carbon dioxide, $\mathrm{CO}$, and $\mathrm{O}_{3}$ concentrations during flight 5 . The shading corresponds to the occurrence of "European-Caspian" air masses (yellow) and "Arctic" air mass. The gray shading corresponds to fast zonal transport, encountered mainly in the mid- and upper-troposphere. 
TABLE 2. Altitudes and tracer concentrations associated with the European and Arctic classes.

\begin{tabular}{|c|c|c|c|c|}
\hline Class & Altitude $(\mathbf{m})$ & $\mathbf{C O}_{\mathbf{2}}(\mathbf{p p m}) *$ & $\mathbf{C O}(\mathbf{p p b}) *$ & $\mathbf{O}_{3}(\mathbf{p p b}) *$ \\
\hline European-Caspian & $\sim 2500$ & $375.63 \pm 1.97$ & $122.29 \pm 14.53$ & $53.43 \pm 6.72$ \\
\hline Arctic & $900-1700$ & $372.53 \pm 1.67$ & $102.71 \pm 4.30$ & $34.92 \pm 3.24$ \\
\hline
\end{tabular}

* Values are given as mean \pm one std dev.

high-latitude vegetation surface uptake must also have contributed to low $\mathrm{CO}_{2}$ and $\mathrm{O}_{3}$ concentrations through photosynthesis and $\mathrm{O}_{3}$ dry deposition, respectively.

In contrast, all polluted layers from EuropeanCaspian Sea origin contain high CO concentrations (Table 2; yellow shading in Fig. 9). FLEXPART attributes the elevated $\mathrm{CO}$ concentration in these layers to a mixture of anthropogenic (fossil fuel combustion) CO emissions from Europe ( $10 \mathrm{ppb})$ and biomass burning CO emissions from the Caspian Sea region ( $\sim 10 \mathrm{ppb}$, probably from agricultural burning in northern Kazakhstan, $50^{\circ} \mathrm{N}, 50^{\circ}-70^{\circ} \mathrm{E}$ ). Comparably to this case study, Pochanart et al. (2003) found in southern Siberia a difference of median CO concentrations of $24 \mathrm{ppb}$ between polluted air masses from Europe and cleaner air masses from the Arctic.

Because of $\mathrm{O}_{3}$ production from precursors coemitted with $\mathrm{CO}$ in anthropogenic emissions and/or biomass burning plumes, one would expect a significant positive $\mathrm{CO}: \mathrm{O}_{3}$ correlation in the polluted air mass sampled during this flight. Such a correlation is indeed seen in individual plumes with European-Caspian origin. In the plume with the highest $\mathrm{CO}$ concentration (144 $\pm 14 \mathrm{ppb}$, Fig. 9), the positive $\mathrm{CO}: \mathrm{O}_{3}$ correlation is high $\left(R^{2}=0.68, \mathrm{n}=90\right)$ and the regression slope is 0.24 , a ratio typical of ozone production from fire-emitted precursors. Another polluted airstream, however, exhibited an unusual negative correlation. The resulting regression slope was $-0.10 \mathrm{ppb} \mathrm{ppb}^{-1}\left(R^{2}=0.39, \mathrm{n}=108\right.$; Fig. 9; $\mathrm{CO}=135 \pm 9 \mathrm{ppb})$. The photochemical processes leading to negative $\mathrm{CO}: \mathrm{O}_{3}$ regression slope in biomass burning plumes remain debated (Val Martin et al. 2006; Real et al. 2007). The two polluted plumes of flight 7 are advected at $2.5-\mathrm{km}$ altitude. Both contain low $\mathrm{CO}_{2}$ concentrations with a high but negative $\mathrm{CO}_{2}$ : $\mathrm{CO}$ correlation $\left(R^{2} \approx 0.80\right.$, regression slopes range between -0.06 and $-0.09 \mathrm{ppb} \mathrm{ppm}^{-1}$ ) in these plumes. In the absence of $\mathrm{CO}_{2}$ sources or sinks other than combustion, the enhancement of $\mathrm{CO}$ should always be paralleled by high $\mathrm{CO}_{2}$ values. The opposite observation suggests that $\mathrm{CO}_{2}$ uptake by plants offsets the $\mathrm{CO}_{2}$ enhancement due to combustion emissions.

Uplift and transport of pollution from China (April 2006). We focus here on the massive uplift of $\mathrm{CO}$ observed
A
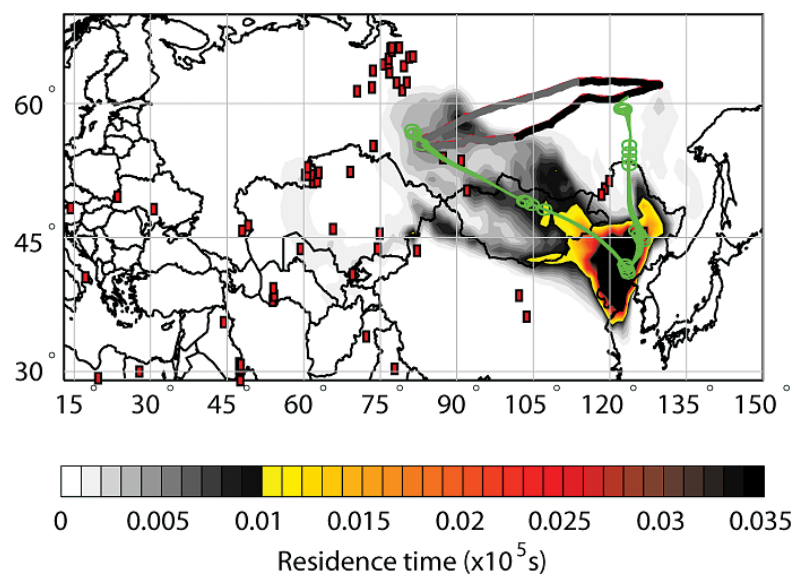

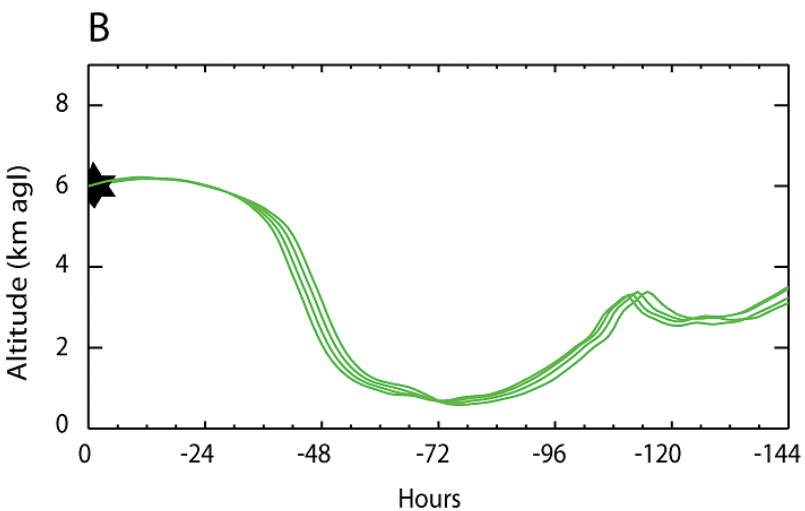

Fig. 10. (a) Footprint of the high CO concentrations (CO>220 ppb) computed using the FLEXPART model. FLEXPART releases a large number of particles at the receptor (instrument) location and computes timereversed transport using European Centre for Medium-Range Weather Forecasts (ECMWF) reanalysis wind fields. The color scale represents the PES in the lowest $1500 \mathrm{~m}$ and therefore the sensitivity to emissions occurring in these areas. The green curves represent three typical high $\mathrm{CO}$ back trajectories computed using the HYSPLIT model. (b) The variation of altitude with time is plotted for these three back trajectories. 
during the April 2006 campaign. Abnormally high $\mathrm{CO}$ values in excess of $90 \mathrm{ppb}$ above the background were detected between 5- and 7-km altitude, together with high $\mathrm{CO}_{2}$ values, on the easternmost flight track, on 12 April 2006. Because of its high altitude, this high $\mathrm{CO}$ air mass must originate from remote sources, which we investigated using FLEXPART and back trajectories from the Hybrid Single-Particle Lagrangian Integrated Trajectory (HYSPLIT) model, version 4 (Draxler and Hess 1997).

Figure 10 shows the average FLEXPART PES over all observations with high CO (>220 ppb). The complementary back-trajectory HYSPLIT simulation was run 6 days backward only. Both FLEXPART PES and HYSPLIT simple trajectories reveal that sources in northeast China and Mongolia are the main contributor to the observed excess of $\mathrm{CO}$ and $\mathrm{CO}_{2}$. These emissions were transported quickly within 24 hours to the aircraft sampling location (Fig. 10b). In addition to obvious fossil fuel $\mathrm{CO}$ and $\mathrm{CO}_{2}$ emissions, fires were also active during that period in Mongolia. The retrotransport calculations cannot discriminate between these two distinct sources, but the measured $\mathrm{CO}: \mathrm{CO}_{2}$ ratios rather suggest a dominant fossil fuel origin. During the uplift episode, the transport of $\mathrm{CO}$ and other pollutants into the Siberian troposphere was caused by a series of extratropical cyclones and their associated WCB. These WCB over eastern Asia are important to the trans-Pacific pollution transport (Yienger et al. 2000). As evidence is growing of Asian emissions increasingly affecting Arctic pollution (Rahn et al. 1977; Shaw 1982; Cahill 2003), the process of northward transport across Siberia such as sampled by the April 2006 campaign needs further investigation.

\section{CONCLUSIONS AND FUTURE OUTLOOK.}

The main achievement of the YAK-AEROSIB ongoing atmospheric campaigns has been to measure the large-scale tropospheric $\mathrm{CO}_{2}, \mathrm{CO}$, and $\mathrm{O}_{3}$ composition in Siberia, where few observations were previously available. We have described five campaigns carried out in April 2006, September 2006, August 2007 , and early and late July 2008 . The Siberian troposhere was sampled with a densely spaced sequence of ascents up to $7 \mathrm{~km}$ and descents to $\sim 500 \mathrm{~m}$.

The resulting ensemble of vertical profiles is appropriate to discriminate global tracer transport model skills in simulating $\mathrm{CO}_{2}$ concentrations at a scale intermediate between the continental and synoptic scales, including the "seasonal rectifier effect" issue. For instance, the $3 \mathrm{D} \mathrm{CO}_{2}$ field obtained by the LMDz-INCA model is found to be inconsistent with observed synoptic features but consistent with largescale observed horizontal and vertical $\mathrm{CO}_{2}$ gradients. Notably, the thickness of the BL air characterized by low $\mathrm{CO}_{2}$ values was modeled rather correctly during the September 2006 campaign but not during the more convective August 2007 campaign. The seasonal (April 2006 minus August 2007) amplitude of vertically averaged $\mathrm{CO}_{2}$ above Siberia is $20 \mathrm{ppm}$ in the lower troposhere below $3 \mathrm{~km}$ and $8 \mathrm{ppm}$ in the midtroposphere (above $5 \mathrm{~km}$ ).

Lagrangian modeling disentangled the contribution of European anthropogenic $\mathrm{CO}$ sources to the observed CO concentration field over Siberia from other sources. In the case of layers with high $\mathrm{CO}$ concentrations in September 2006, a European CO enhancement was found to be comparable to the $\mathrm{CO}$ enhancement caused by central Asian biomass burning emissions, that is, $\sim 10 \mathrm{ppb}$.

Global tracer transport model calculations of the dispersion of $\mathrm{CO}_{2}$ and anthropogenic pollutants can be falsified against our data, notably the vertical profile of $\mathrm{CO}_{2}$. Furthermore, Lagrangian model-based source apportionment for $\mathrm{CO}, \mathrm{CO}_{2}$, and $\mathrm{O}_{3}$ enhancements in the troposphere can separate the different source regions that affect the Siberian airshed, and potentially the Arctic. In this context, the latest campaign carried out in July 2008, along a new itinerary that sampled the Siberian Arctic coast, can further inform us on atmospheric transport between Siberia and the Arctic.

Future YAK-AEROSIB activities will include analysis of the data just collected during a recent campaign in April 2010, with a set of instruments including the one described here, as well as improved aerosol and methane measurements. Future campaigns with an enhanced payload, in particular flask air sampling and online $\mathrm{CH}_{4}$ measurements, could increase the value of the dataset already acquired and further improve our understanding of the atmospheric composition and transport, and atmosphere-biosphere exchange, over observationsparse Siberia.

ACKNOWLEDGMENTS. The authors acknowledge funding of the YAK-AEROSIB project from the CNRS (France), the French Ministry of Foreign Affairs, CEA (France), RAS (Russia), and RFBR (Russia). The POLARCAT campaigns were funded by an ANR grant. A. Stohl acknowledges funding from the Norwegian Research Council in the framework of the POLARCAT project, which also supported one campaign. D. Filippi developed the $\mathrm{CO}_{2}$ instrument. The flight crews are thanked for the operations. F. Boumard, A. Royer, J. M. Cousin, G. Athier, 
and G. Cayez contributed to operations of the instruments. J. L. Teffo brought invaluable support throughout the whole life cycle of this project. P. Bousquet and L. Klenov contributed to the model runs.

\section{APPENDIX: AIRCRAFT AND INSTRUMENT} DESCRIPTIONS. The two-propeller Antonov-30 aircraft OPTIK-E operated by the Institute of Atmospheric Optics of Tomsk (Zuev et al. 1992) is equipped for meteorological measurements. Aircraft horizontal speed during measurement is about $85 \mathrm{~m} \mathrm{~s}^{-1}$ and vertical speed is about $3.5 \mathrm{~m} \mathrm{~s}^{-1}$ on ascent and $7 \mathrm{~m} \mathrm{~s}^{-1}$ on descent during profiles.

The $\mathrm{CO}_{2}$ analyzer is a modified nondispersive infrared (NDIR) analyzer LI-COR 6262 (Paris et al. 2008, see Table A1). The instrument is regulated for temperature, flow, and pressure. Incoming air is chemically dried. Three calibration gases, traceable to a suite of primary World Meteorological Organization (WMO) $\mathrm{CO}_{2}$ standards from the National Oceanic and Atmospheric Administration/Earth System Research Laboratory (NOAA/ ESRL), bracketing ambient concentrations are used sequentially ( 3 minutes each) at $~ 30$-min intervals in order to cope with potential drift of the measurement. Approximately $5 \%$ of the data were rejected on average based on pressure, flow, and temperature anomalies.

The $\mathrm{O}_{3}$ analyzer is a modified model 49 (Thouret et al. 1998, Table A1) of Thermo Environmental Instruments (TEI), with added internal calibration and compensated pressure and temperature. It is based on UV absorption in two parallel ("zero" and sample) cells. Laboratory calibration with a $\mathrm{O}_{3}$ generator is performed before and after the campaigns.

The CO analyzer (Nédélec et al. 2003, Table A1) is a heavily modified IR gas filter correlation analyzer TEI model 48C. Periodical accurate zero measurements, new IR detector with better cooling and temperature regulation, pressure increase and regulation in the absorption cell, increased flow rate to $4 \mathrm{~L} \mathrm{~min}^{-1}$, water vapor trap (Nafion membrane), and ozone filter have been introduced. Air sent to the $\mathrm{CO}$ and $\mathrm{O}_{3}$ analyzers is compressed using a Teflon KNF Neuberger N735 pump.

Aerosols are measured using a diffusion battery (Reischl et al. 1991; Arshinov et al. 2007) but are presented in another paper (Paris et al. 2009). Meteorological parameters are measured routinely on board using HYCAL sensor model IH-3602-C Honeywell.

\section{REFERENCES}

Andreae, M. O., and Coauthors, 1988: Vertical distribution of dimethylsulfide, sulfur dioxide, aerosol ions, and radon over the northeast Pacific Ocean. J. Atmos. Chem., 6, 149-173.

Arshinov, M. Yu., B. D. Belan, Ph. Nédélec, J.-D. Paris, and T. Machida, 2007: Spatial distribution of nanoparticles in the free troposphere over Siberia. Nucleation and Atmospheric Physics, 17th International Conference on Nucleation and Atmospheric Aerosols, Galway, Ireland, 2007. C. D. O'Dowd and P. E. Wagner, Eds., Springer, 819-823.

Baker, D. F., S. C. Doney, and D. S. Schimel, 2006: Variational data assimilation for atmospheric $\mathrm{CO}_{2}$. Tellus, 58, 359-365.

Brunner, D., and Coauthors, 2005: An evaluation of the performance of chemistry transport models-Part 2: Detailed comparison with two selected campaigns, Atmos. Chem. Phys., 5, 107-129.

Cahill, C. F., 2003: Asian aerosol transport to Alaska during ACE-Asia. J. Geophys. Res., 108, 8664, doi:10.1029/2002JD003271.

Chan D., C. W. Yuen, K. Higuchi, A. Shashkov, J. Liu, J. Chen, and D. Worthy, 2004: On the $\mathrm{CO}_{2}$ exchange between the atmosphere and the biosphere: The role of synoptic and mesoscale processes. Tellus, 56B, 194-212.

\begin{tabular}{|c|c|c|c|c|}
\hline TABLE AI. Instrument characteristics. \\
\hline Species measured & Core technique & Acquisition frequency & Accuracy & Reference \\
\hline $\mathrm{CO}_{2}$ & NDIR & $2 \mathrm{~s}$ & $0.15 \mathrm{ppm}$ & Paris et al. 2008 \\
\hline $\mathrm{CO}$ & Gas filter correlation & $\mathrm{I} \mathrm{s}$ & $5 \mathrm{ppb} / 5 \%$ & Nédélec et al. 2003 \\
\hline $\mathrm{O}_{3}$ & UV absorption & $4 \mathrm{~s}$ & $2 \mathrm{ppb} / 2 \%$ & Paris et al. 2008 \\
\hline Aerosols concentration & Diffusion battery & $\mathrm{I} \mathrm{min}$ & $10 \%$ & Reischl et al. 199I \\
\hline Relative humidity & & $\mathrm{Is}$ & $7 \%$ & Zuev et al. 1992 \\
\hline Temperature & & $\mathrm{Is}$ & $0.5^{\circ} \mathrm{C}$ & Zuev et al. 1992 \\
\hline
\end{tabular}

* After 30-s slide averaging. 
Denning, A. S., T. Takahashi, and P. Friedlingstein, 1999: Can a strong atmospheric $\mathrm{CO}_{2}$ rectifier effect be reconciled with a "reasonable" carbon budget? Tellus, 51B, 249-253.

Draxler, R. R., and G. D. Hess, 1997: Description of the Hysplit_4 modeling system. NOAA ERL Tech. Memo. ARL-224, 24 pp.

Duncan, B. N., and I. Bey, 2004: A modeling study of the export pathways of pollution from Europe: Seasonal and interannual variations (1987-1997). J. Geophys. Res., 109, D08301, doi:10.1029/2003JD004079.

Edwards, D. P., and Coauthors, 2004: Observations of carbon monoxide and aerosols from the Terra satellite: Northern Hemisphere variability. J. Geophys. Res., 109, D24202, doi:10.1029/2004JD004727.

Fehsenfeld, F., and Coauthors, 1992: Emissions of volatile organic compounds from vegetation and implications for atmospheric chemistry. Global Biogeochem. Cycles, 6, 389-430.

Goldstein, A. H., M. McKay, M. R. Kurpius, G. W. Schade, A. Lee, R. Holzinger, and R. A. Rasmussen, 2004: Forest thinning experiment confirms ozone deposition to forest canopy is dominated by reaction with biogenic VOCs. Geophys. Res. Lett., 31, L22106, doi:10.1029/2004GL021259.

Gurney, K. R., and Coauthors, 2002: Towards robust regional estimates of $\mathrm{CO}_{2}$ sources and sinks using atmospheric transport models. Nature, 415, 626-630, doi:10.1038/415626a.

Hauglustaine, D. A., F. Hourdin, L. Jourdain, M. A. Filiberti, S. Walters, J. F. Lamarque, and E. A. Holland, 2004: Interactive chemistry in the Laboratoire de Météorologie Dynamique general circulation model: Description and background tropospheric chemistry evaluation. J. Geophys. Res., 109, D04314, doi:10.1029/2003JD003957.

Heald, C. L., and Coauthors, 2004: Comparative inverse analysis of satellite (MOPITT) and aircraft (TRACE-P) observations to estimate Asian sources of carbon monoxide. J. Geophys. Res., 109, D23306, 10.1029/2004JD005185.

Kalnay, E., and Coauthors, 1996: The NCEP/NCAR 40-Year Reanalysis Project. Bull. Amer. Meteor. Soc., 77, 437-471.

Korontzi, S., J. McCarty, T. Loboda, S. Kumar, and C. Justice, 2006: Global distribution of agricultural fires in croplands from 3 years of Moderate Resolution Imaging Spectroradiometer (MODIS) data. Global Biogeochem. Cycles, 20, GB2021, doi:10.1029/2005GB002529.

Law, R. M., and Coauthors, 1996: Variations in modeled atmospheric transport of carbon dioxide and the consequences for $\mathrm{CO}_{2}$ inversions. Global Biogeochem. Cycles, 10, 783-796.
Lelieveld, J., and Coauthors, 2002: Global air pollution crossroads over the Mediterranean. Science, 298, 794-799.

Levin, I., and Coauthors, 2002: Three years of trace gas observations over the EuroSiberian domain derived from aircraft sampling: A concerted action. Tellus, 54B, 696-712.

Lloyd, J., and Coauthors, 2002: A trace-gas climatology above Zotino, central Siberia. Tellus, 54B, 749-767.

Machida, T., T. Nakazawa, S. Ishidoya, S. Maksyutov, Y. Tohjima, 2001: Temporal and spatial variations of atmospheric CO2 mixing ratio over Siberia. Proc. Sixth Int. Carbon Dioxide Conf., Sendai, Japan, Organizing Committee of Sixth International Carbon Dioxide Conference, 15-18.

Maignan, F., F. M. Breon, E. Vermote, P. Ciais, and N. Viovy, 2008: Mild winter and spring 2007 over western Europe led to a widespread early vegetation onset. Geophys. Res. Lett., 35, L02404, doi:10.1029/2007GL032472.

Marenco, A., and Coauthors, 1998: Measurement of ozone and water vapor by Airbus in-service aircraft: The MOZAIC airborne program: An overview. J. Geophys. Res., 103, 25 631-25 642.

Nédélec, P., and Coauthors, 2003: An improved infrared carbon monoxide analyser for routine measurements aboard commercial Airbus aircraft: Technical validation and first scientific results of the MOZAIC III programme. Atmos. Chem. Phys., 3, 1551-1564.

Newell, R. E., and M. J. Evans, 2000: Seasonal changes in pollutant transport to the North Pacific: The relative importance of Asian and European sources. Geophys. Res. Lett., 27, 2509-2512.

Olivier, J. G. J., J. A. Van Aardenne, F. Dentener, L. Ganzeveld, and J. A. H. W. Peters, 2005: Recent trends in global greenhouse gas emissions: Regional trends and spatial distribution of key sources. Non$\mathrm{CO}_{2}$ Greenhouse Gases (NCGG-4), A. van Amstel, Ed., Millpress, 325-330.

Paris, J.-D., and Coauthors, 2008: The YAK-AEROSIB transcontinental aircraft campaigns: New insights on the transport of $\mathrm{CO}_{2}, \mathrm{CO}$ and $\mathrm{O}_{3}$ across Siberia. Tellus, 60B, 551-568.

—, M. Yu. Arshinov, P. Ciais, B. D. Belan, and P. Nédélec, 2009: Large-scale aircraft observations of ultra-fine and fine particle concentrations in the remote Siberian troposphere: New particle formation studies. Atmos. Environ., 43, 1302-1309.

—, A. Stohl, P. Ciais, P. Nédélec, B. D. Belan, M. Y. Arshinov, and M. Ramonet, 2010: Source-receptor relationships for airborne measurements of $\mathrm{CO}_{2}$, $\mathrm{CO}$ and $\mathrm{O}_{3}$ above Siberia: A cluster-based approach. Atmos. Chem. Phys., 10, 1671-1687. 
Pochanart, P., H. Akimoto, Y. Kajii, V. M. Potemkin, and T. V. Khodzher, 2003: Regional background ozone and carbon monoxide variations in remote Siberia/East Asia. J. Geophys. Res., 108, 4028, doi:10.1029/2001JD001412.

Potter, C. S., J. T. Randerson, C. B. Field, P. A. Matson, P. M. Vitousek, H. A. Mooney, and S. A. Klooster, 1993: Terrestrial ecosystem production: A process model based on global satellite and surface data. Global Biogeochem. Cycles, 7, 811-841.

Rahn, K. A., R. D. Borys, and G. E. Shaw, 1977: Asian source of Arctic haze bands. Nature, 268, 713-715.

Ramonet, M., and Coauthors, 2002: Three years of aircraft-based trace gas measurements over the Fyodorovskoye southern taiga forest, $300 \mathrm{~km}$ northwest of Moscow. Tellus, 54B, 713-734.

Rayner, P. J., and R. M. Law, 1995: A comparison of modelled responses to prescribed $\mathrm{CO}_{2}$ sources. Tech. Paper 36, CSIRO Division of Atmospheric Research, 84 pp.

Real, E., and Coauthors, 2007: Processes influencing ozone levels in Alaskan forest fire plumes during longrange transport over the North Atlantic. J. Geophys. Res., 112, D10S41, doi:10.1029/2006JD007576.

Reichstein, M., and Coauthors, 2007: Determinants of terrestrial ecosystem carbon balance inferred from European eddy covariance flux sites. Geophys. Res. Lett., 34, L01402, doi:10.1029/2006GL027880.

Reischl, G. P., A. Majerowicz, A. Ankilow, S. Eremenko, and R. Mavliev, 1991: Comparison of the Novosibirsk automated diffusion battery with the Vienna electro mobility spectrometer. J. Aerosol Sci., 22, 223-228.

Sadourny, R., and K. Laval, 1984: January and July performance of the LMD general circulation model. New Perspectives in Climate Modelling, A. Berger and C. Nicolis, Eds., Elsevier, 414 pp.

Sarrat, C., and Coauthors, 2007: Atmospheric $\mathrm{CO}_{2}$ modeling at the regional scale: Application to the CarboEurope Regional Experiment. J. Geophys. Res., 112, D12105, doi:10.1029/2006JD008107.

Seibert, P., and A. Frank, 2004: Source-receptor matrix calculation with a Lagrangian particle dispersion model in backward mode. Atmos. Chem. Phys., 4, 51-63.

Shaw, G. E., 1982: Evidence for a Central Eurasian source area of Arctic haze in Alaska. Nature, 299, 815-818.

Shibistova, O., and Coauthors, 2002: Seasonal and spatial variability in soil $\mathrm{CO}_{2}$ efflux rates for a central Siberian Pinus sylvestris forest. Tellus, 54B, 552-567.

Shvidenko, A., D. Schepaschenko, I. McCallum, and S. Nilsson, cited 2007: Russian forests and forestry. International Institute for Applied Systems Analysis and the Russian Academy of Science, CD-ROM. [Available online at www.iiasa.ac.at/Research/FOR/ forest_cdrom/.]

Smith N. V., S. S. Saatchi, and J. T. Randerson, 2004: Trends in high northern latitude soil freeze and thaw cycles from 1988 to 2002. J. Geophys. Res., 109, D12101, doi:10.1029/2003JD004472.

Stephens, B. B., and Coauthors, 2007: Weak northern and strong tropical land carbon uptake from vertical profiles of atmospheric $\mathrm{CO}_{2}$. Science, 316, 1732-1735.

Stohl, A., 2001: A one-year Lagrangian climatology of airstreams in the northern hemisphere troposphere and lowermost stratosphere. J. Geophys. Res., 106, 7263-7279.

- 2006: Characteristics of atmospheric transport into the Arctic troposphere. J. Geophys. Res., 111, D11306, doi:10.1029/2005JD006888.

- , and S. Eckhardt, 2004: Intercontinental transport of air pollutants-An introduction. Intercontinental Transport of Air Pollutants, A. Stohl, Ed., SpringerVerlag, 325 pp.

,-- C. Forster, P. James, and N. Spichtinger, 2002: On the pathways and timescales of intercontinental air pollution transport. J. Geophys. Res., 107, 4684, doi:10.1029/2001JD001396.

—, C. Forster, A. Frank, P. Seibert, and G. Wotawa, 2005: Technical note: The Lagrangian particle dispersion model FLEXPART version 6.2. Atmos. Chem. Phys., 5, 2461-2474.

Tarvainen, V., H. Hakola, J. Rinne, H. Hellen, and S. Haapanala, 2007: Towards a comprehensive emission inventory of terpenoids from boreal ecosystems. Tellus, 59B, 526-534.

Thouret, V., A. Marenco, J. A. Logan, P. Nédélec, and C. Grouhel, 1998: Comparisons of ozone measurements from the MOZAIC airborne program and the ozone sounding network at eight locations. $J$. Geophys. Res., 103, 25 695-25 720.

Val Martin, M., R. E. Honrath, R. C. Owen, G. Pfister, P. Fialho, and F. Barata, 2006: Significant enhancements of nitrogen oxides, black carbon, and ozone in the North Atlantic lower free troposphere resulting from North American boreal wildfires. J. Geophys. Res., 111, D23S60, doi:10.1029/2006JD007530.

Van der Molen, M. K., J. van Huissteden, F. J. W. Parmentier, R. A. M. de Jeu, T. R. H. Holmes, and A. J. Dolman, 2008: Greenhouse gas fluxes at a continental tundra site in NE Siberia and radiative forcing of advancing of the growing season. Geophysical Research Abstracts, Vol. 10, Abstract EGU2008-A-06961. [Available online at www.cosis.net/abstracts/ EGU2008/06961/EGU2008-A-06961.pdf.] 
van der Werf, G. R., J. T. Randerson, L. Giglio, G. J. Collatz, P. S. Kasibhatla, and A. F. Arellano, 2006: Interannual variability in global biomass burning emissions from 1997 to 2004. Atmos. Chem. Phys., 6, 3423-3441.

Wada, A., Y. Sawa, H. Matsueda, S. Taguchi, S. Murayama, S. Okubo, and Y. Tsutsumi, 2007: Influence of continental air mass transport on atmospheric $\mathrm{CO}_{2}$ in the western North Pacific. J. Geophys. Res., 112, D07311, doi:10.1029/2006JD007552.

Wild, O., P. Pochanart, and H. Akimoto, 2004: TransEurasian transport of ozone and its precursors. J. Geophys. Res., 109, D11302, doi:10.1029/2003JD004501.

Wotawa, G., P. C. Novelli, M. Trainer, and C. Granier, 2001: Inter-annual variability of summertime CO concentrations in the Northern Hemisphere explained by boreal forest fires in North America and Russia. Geophys. Res. Lett., 28, 4575-4578.
Yi, C., K. J. Davis, P. S. Bakwin, A. S. Denning, N. Zhang, A. Desai, J. C. Lin, and C. Gerbig, 2004: Observed covariance between ecosystem carbon exchange and atmospheric boundary layer dynamics at a site in northern Wisconsin. J. Geophys. Res., 109, D08302, doi:10.1029/2003JD004164.

Yienger, J. J., M. Galanter, T. A. Holloway, M. J. Phadnis, S. K. Guttikunda, G. R. Carmichael, W. J. Moxim, and H. Levy II, 2000: The episodic nature of air pollution transport from Asia to North America. J. Geophys. Res., 105 (D22), 26 931-26945.

Zhou, L. M., C. J. Tucker, R. K. Kaufmann, D. Slayback, N. V. Shabanov, and R. B. Myneni, 2001: Variations in northern vegetation activity inferred from satellite data of vegetation index during 1981 to 1999. J. Geophys. Res., 106, 20 069-20 083.

Zuev, V. E., and Coauthors, 1992: The Optik-E AN-30 laboratory-airplane for ecological studies. Opt. Atmos. Okeana, 5, 1012-1021.

\section{NEW FROM AMS BOOKS!}

\section{Synoptic-Dynamic Meteorology and Weather Analysis and Forecasting}

\section{A Tribute to Fred Sanders}

LANCE F. BOSART AND HOWARD B. BLUESTEIN, EDS.

Editors Lance F. Bosart (University at Albany, SUNY) and Howard B. Bluestein (University of Oklahoma) have brought together contributions from luminary authors, including Kerry Emanuel, Robert Burpee, Edwin Kessler, and Louis Uccellini, representing key scientific research in the fields of synoptic meteorology, weather analysis, forecasting, and climatology. Dozens of unique photographs pay homage to the vibrant community that developed under Sanders's influence. The result is a tool for educating generations of future weather researchers and a testament to Sanders's legacy of teaching.

LIST \$120 MEMBER \$80 METEOROLOGICAL MONOGRAPH VOL. 33 NO. 55 (c) 2008, HARDCOVER, 440 PAGES, ISBN: 978-1-878220-84-4, AMS CODE: MM55

\section{ORDER TODAY!}

\section{www.ametsoc.org/amsbookstore}

Or see the order form at the back of this magazine.

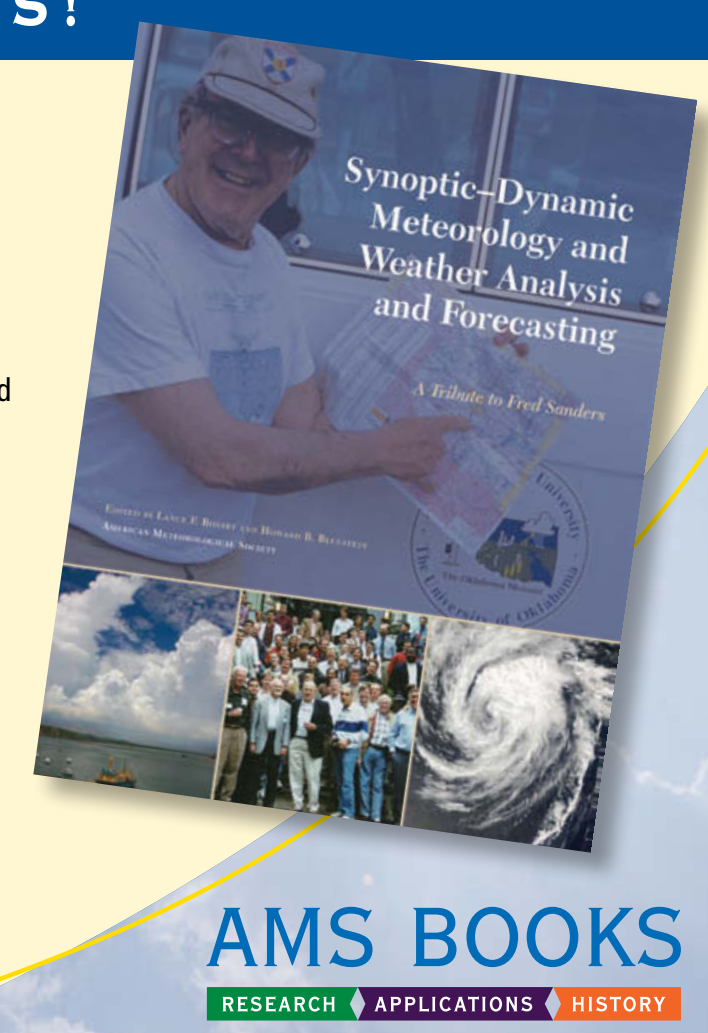




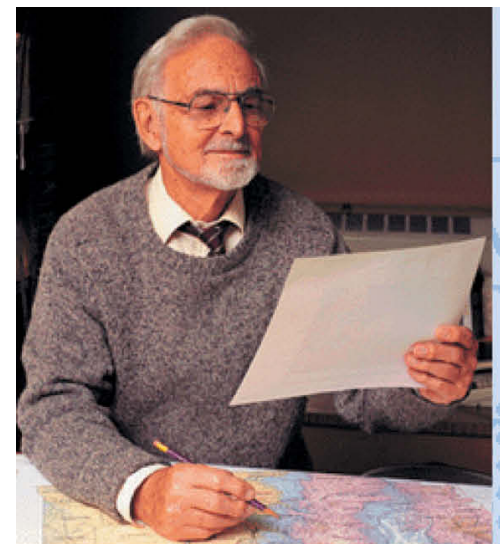

A Half Century of Progress in Meteorology:

A Tribute to Richard Reed

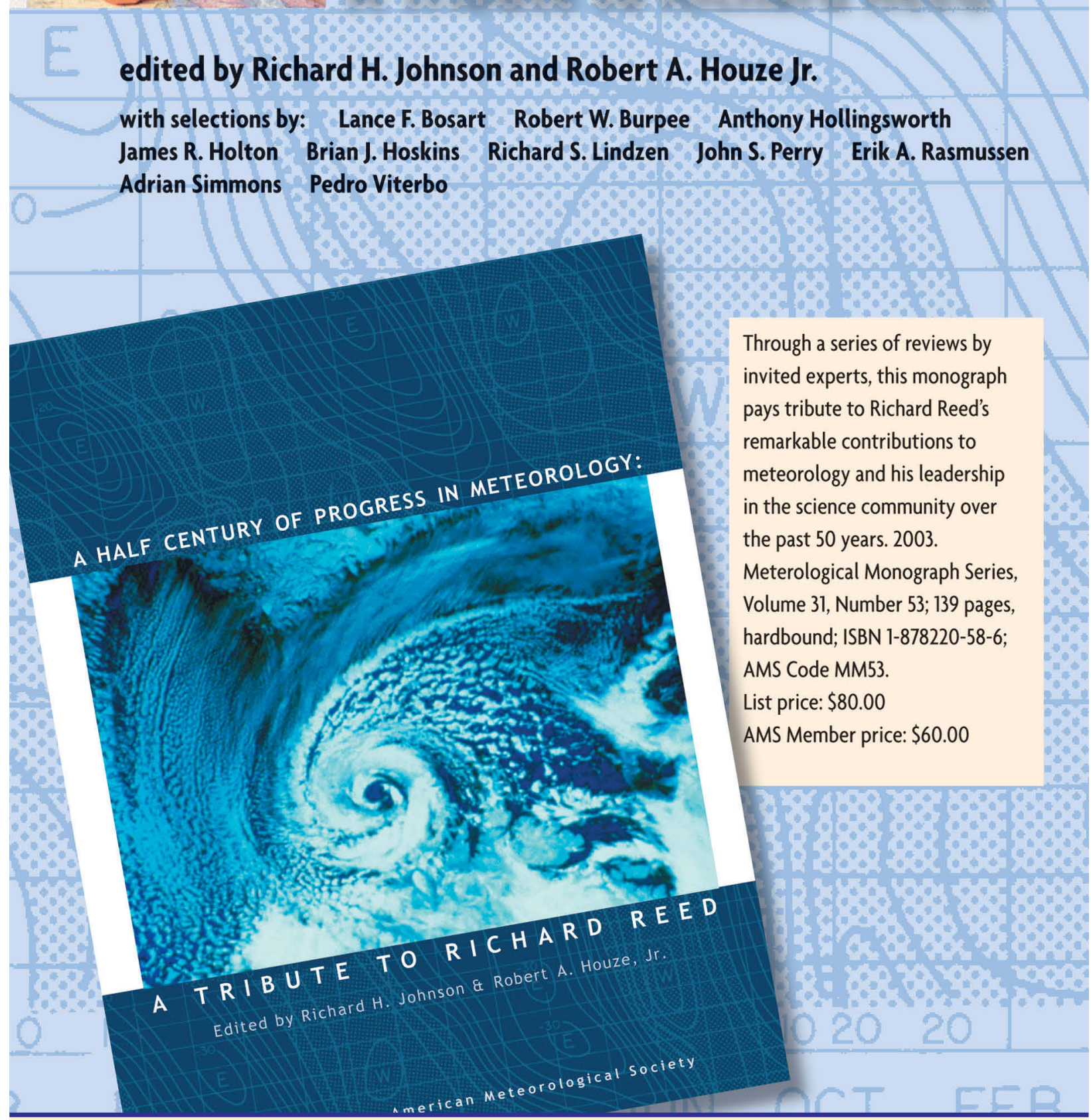

ORDER ONLINE: www.ametsoc.org/amsbookstore or see the order form at the back of this issue 